\title{
Aircraft Loss-of-Control Accident Analysis
}

\author{
Christine M. Belcastro ${ }^{*}$ and John V. Foster ${ }^{\dagger}$ \\ NASA Langley Research Center, Hampton, Virginia, 23681
}

\begin{abstract}
Loss of control remains one of the largest contributors to fatal aircraft accidents worldwide. Aircraft loss-of-control accidents are complex in that they can result from numerous causal and contributing factors acting alone or (more often) in combination. Hence, there is no single intervention strategy to prevent these accidents. To gain a better understanding into aircraft loss-of-control events and possible intervention strategies, this paper presents a detailed analysis of loss-of-control accident data (predominantly from Part 121), including worst case combinations of causal and contributing factors and their sequencing. Future potential risks are also considered.
\end{abstract}

\section{Nomenclature}

$\begin{array}{ll}\text { CAST } & =\text { Commercial Aviation Safety Team } \\ \text { ICAO } & =\text { International Civil Aviation Organization } \\ \text { LOC } & =\text { Loss of Control (in-flight) } \\ \text { NASA } & =\text { National Aeronautics and Space Administration } \\ \text { NextGen } & =\text { Next Generation Airspace Operations Concept } \\ \text { NTSB } & =\text { National Transportation Safety Board } \\ \text { PIO } & =\text { Pilot Induced Oscillation }\end{array}$

\section{Introduction}

T oss of control remains one of the largest contributors to fatal aircraft accidents. As shown in Figure 1, in-flight Lloss of control (LOC) is the largest fatal accident category for commercial jet airplane accidents worldwide occurring from 1999 through 2008, and resulted in 22 accidents and 1,991 total fatalities. ${ }^{1}$ Aircraft loss of control is a significant contributor to accidents and fatalities across all vehicle classes, operational categories, and phases of flight. It is also a highly complex event, usually resulting from multiple causal and contributing factors that can occur individually or (more often) in combination. There is therefore no single intervention strategy that can be readily identified to prevent LOC accidents. In order to develop effective intervention strategies for preventing LOC accidents, it is necessary to analyze how these events unfold. In Reference [2], 74 LOC accidents were reviewed for the time period 1993 - 2007, which resulted in 42 hull loss accidents and 3241 fatalities. The analysis of this reference groups the accidents into the categories aerodynamic stall, flight control system, spatial disorientation of the crew, contaminated airfoil, and atmospheric disturbance. There is also a detailed discussion of accidents in each of these categories and a comparison with older accidents that occurred prior to 1993 in order to identify emerging trends. This reference also provides a definition of aircraft upset conditions, which is defined therein as "any uncommanded or inadvertent event with an abnormal aircraft attitude, rate of change of aircraft attitude, acceleration, airspeed, or flight trajectory". As also noted in Ref. [2], "abnormal" must be determined relative to phase of flight and aircraft type. Reference [3] contains an analysis of LOC accidents between 1988 and 2004 relative to operational categories, including Parts 121, 135, and 91. This report states that "in flight loss of control is a serious aviation problem", and that "well over half of the loss of control accidents included at least one fatality (80\% in Part 121), and roughly half of all aviation fatalities in the studied time period occurred in conjunction with loss of control". The study of Ref. [3] also found that about 30\% of Part 121 loss of control accidents involved system/component failure/malfunction, and that icing and adverse winds were also the primary cause of many

\footnotetext{
* Senior Researcher, Dynamic Systems and Control Branch, MS 308, E-Mail: christine.m.belcastro@nasa.gov; AIAA Senior Member.

† Senior Researcher, Flight Dynamics Branch, MS 308, E-Mail: john.v.foster@nasa.gov; AIAA Senior Member.
} 
accidents. In 2009, NASA commissioned an independent study of aircraft loss of control. ${ }^{4}$ The final report from this study organized causal and contributing factors into human-induced, environmentally-induced, and systemsinduced categories and concluded that "no single category is solely responsible for loss of control accidents" and that "accidents occur when combinations of breakdowns happen across human and engineering systems, and often in the presence of threats posed by the external environment". This report further states that "a sympathetic read of the loss of control accidents should leave one with little hope of reducing them if efforts toward improvement were aimed in a single direction or within a single category”.

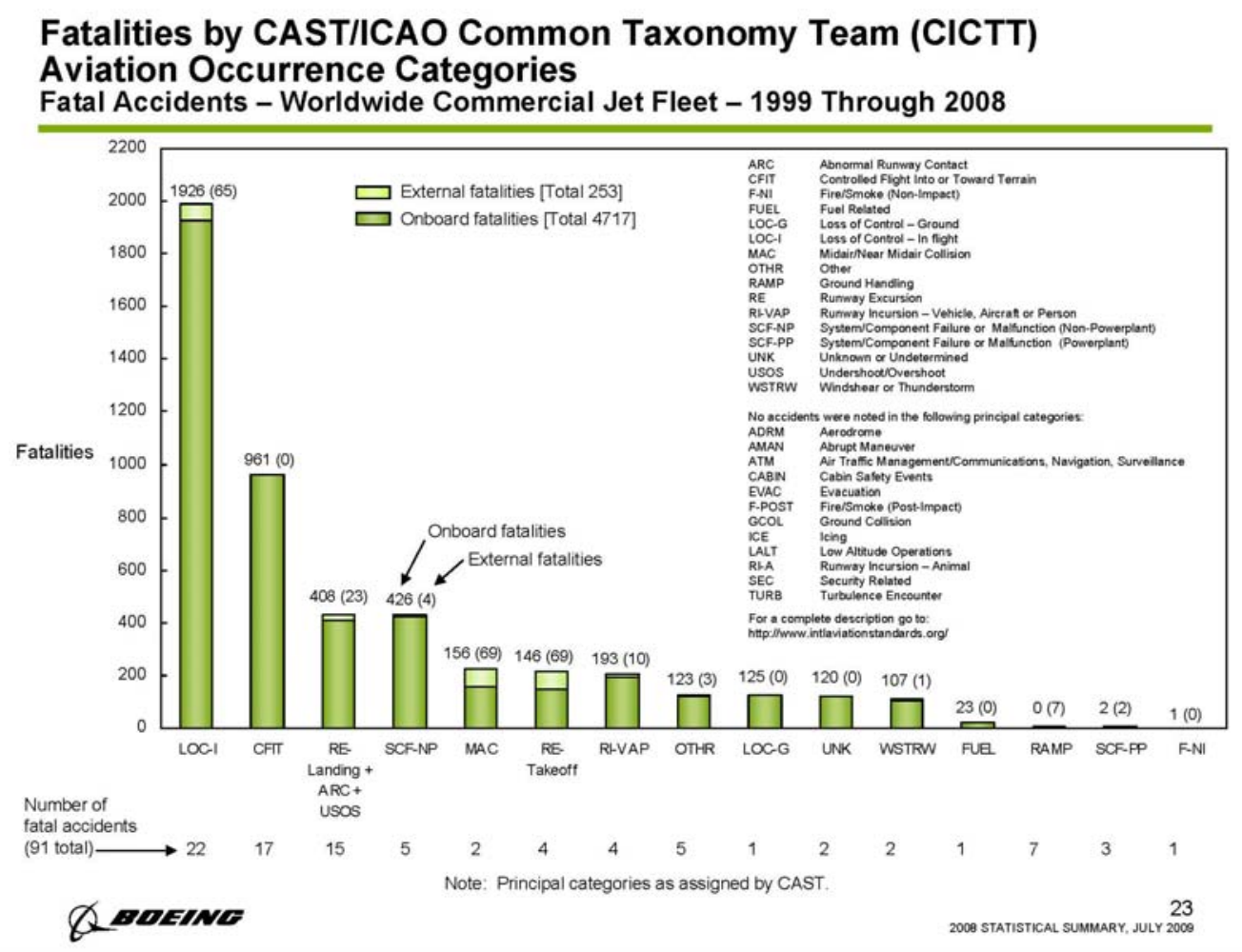

Figure 1. Aircraft Accident Statistics for Worldwide Commercial Jet Fleet, 1999 - 2008.

In this paper, the analysis seeks to identify worst case combinations and sequencing of precursors to aircraft LOC accidents that were predominantly from the Part 121 category operations (both large transports and smaller regional aircraft). These LOC accident precursors are called "causal and contributing factors" throughout this paper. The LOC accidents considered in this paper included accidents that involved vehicle upsets, as well as those involving failures, impairment, or damage to the flight control capability of the aircraft (including control surfaces, flight control system or components, and the engines) or to the vehicle airframe (when the damage was sufficient to alter vehicle dynamics and control characteristics) whether or not they led to an upset condition (or there was evidence of upset cited in the report). Causal and contributing factors were identified from reading the full reports available for each accident (not through key word search), and these factors were categorized into three groups so that worst case combinations and sequences could be identified. In understanding combinations of loss-of-control factors and how they occur sequentially, it may be possible to develop a holistic intervention strategy for breaking the sequences that result in loss of control accidents. This is the primary motivation for the LOC accident analysis presented in this paper. Section II contains the analysis results, and conclusions are given in Section III. 


\section{Aircraft Loss-of-Control Accident Analysis}

A review of 126 LOC accidents (predominantly from Part 121, including large transports and smaller regional carriers) occurring between 1979 and 2009 (30 years) and resulting in 6087 fatalities was performed for the analysis, and a listing of these accidents is provided in the Appendix. This accident set does not represent an exhaustive search throughout this time period, and it does not include military, private, cargo, charter, and corporate accidents. Russian aircraft accidents were also excluded due to a general lack of detailed information in the associated reports. Of this total accident set, 91 accidents resulting in 4190 fatalities occurred between 1994 and 2009 (15 years). The review was based on accident reports available on the Aviation Safety Network ${ }^{5}$ and National Transportation Safety Board (NTSB) ${ }^{6}$ websites. The level of detail in analyzing each accident was therefore dependent on the level of detail provided in the accident reports. Information from each report was transcribed into a categorized set of causal and contributing factors, using the following scheme. The causal and contributing factors were grouped into three categories: adverse onboard conditions, vehicle upsets, and external hazards and disturbances.

Adverse onboard conditions included:

- vehicle impairment (including inappropriate vehicle configuration, contaminated airfoil, and improper vehicle loading);

- system faults, failures, and errors (resulting from design flaws, software errors, or improper maintenance actions);

- vehicle damage to airframe and engines (resulting from fatigue cracks, foreign objects, overstress during upsets or upset recovery, etc.); and

- inappropriate crew response (including pilot-induced oscillations, spatial disorientation, mode confusion, ineffective recoveries, crew impairment, and failures to take appropriate actions).

External hazards and disturbances included:

- poor visibility;

- wake vortices;

- wind shear, turbulence, and thunderstorms;

- snow and icing conditions; and

- abrupt maneuvers for obstacle avoidance or collisions.

Vehicle upsets included:

- abnormal attitude;

- abnormal airspeed, angular rates, or asymmetric forces;

- abnormal flight trajectory;

- uncontrolled descent (including spiral dive); and

- stall/departure (including falling leaf and spin).

A basic analysis of the contributions of each causal/contributing factor to the 126 accidents is given in Table 1. It should be noted in Table 1 that the factors are not mutually exclusive. For example, 119 LOC accidents involved one or more adverse onboard conditions, and the frequency of each individual factor within this category is listed. These numbers do not add up to 119, however, because there were many accidents involving more than one subfactor. Similarly, adding the number of accidents listed for the three categories exceeds the 126 total because many accidents involved multiple categories. The 23 accidents related to vehicle damage consisted of 20 airframe and system damage conditions, and 3 engine damage conditions. Table I is useful for determining the number of accidents and fatalities associated with individual causal and contributing factors, but it does not provide any information on combinations or sequencing of these factors. Nonetheless, this table identifies System Faults/Failures/Errors, Vehicle Impairment/Damage, Inappropriate Crew Response, Stall/Departure, Atmospheric Disturbances related to Wind Shear/Gusts, and Snow/Icing as the most significant contributors to the number of fatalities. The following subsections A and B address combinations and sequencing of LOC causal and contributing factors, respectively. Subsection C addresses future risks. 
Table 1. Contributions to LOC Accidents and Fatalities by Individual Causal and Contributing Factors

\begin{tabular}{|c|c|c|c|c|}
\hline Factor & Accidents & $\%$ & Fatalities & $\%$ \\
\hline Adverse Onboard Conditions & 119 & 94.4 & 5683 & 93.4 \\
\hline Vehicle Impairment & 33 & 26.2 & 1134 & 18.6 \\
\hline System Faults / Failures / Errors & 57 & 45.2 & 2807 & 46.1 \\
\hline Vehicle Damage & 23 & 18.2 & 1780 & 29.2 \\
\hline Inappropriate Crew Response & 54 & 42.8 & 2818 & 46.3 \\
\hline Vehicle Upsets & 98 & 77.8 & 4523 & 74.3 \\
\hline Abnormal Attitude & 18 & 14.3 & 219 & 3.60 \\
\hline Abnormal Airspeed / Angular Rates / Asymmetric Forces & 14 & 11.1 & 701 & 11.5 \\
\hline Abnormal Flight Trajectory & 4 & 3.2 & 272 & 4.47 \\
\hline Uncontrolled Descent & 15 & 11.9 & 773 & 12.7 \\
\hline Stall / Departure & 49 & 38.9 & 2622 & 43.1 \\
\hline External Hazards \& Disturbances & 61 & 48.4 & 3246 & 53.3 \\
\hline Poor Visibility & 9 & 7.1 & 556 & 9.1 \\
\hline Wake Vortices & 4 & 3.2 & 402 & 6.6 \\
\hline Wind Shear / Gusts / Thunderstorms & 18 & 14.3 & 1126 & 18.5 \\
\hline Snow / Icing & 28 & 22.2 & 595 & 9.8 \\
\hline Abrupt Maneuver / Collision & 3 & 2.4 & 189 & 3.1 \\
\hline
\end{tabular}

\section{A. Analysis of Causal and Contributing Factor Combinations}

In order to identify worst case combinations of LOC causal and contributing factors (as defined by number of accidents and resulting fatalities), 3-dimensional scatter plots were generated, and Figure 2 shows the first such plot. The three dimensions are aligned with the three categories identified in Table 1. Sphere size is directly proportional to the number of accidents, and sphere color depicts the number of fatalities as indicated by the legend. As indicated in Figure 2, worst case combinations include: system faults and failures occurring alone and in combination with upsets, icing conditions resulting in vehicle impairment, and inappropriate crew response combined with upset conditions. There are also a significant number of accidents and fatalities resulting from: vehicle damage occurring alone and combined with upsets, icing combined with inappropriate crew response and upsets, and wind shear and turbulence combined with inappropriate crew response and vehicle upsets. It should be noted that there is some overlap (i.e., some combinations that are not mutually exclusive) in the scatter plot of Figure 2, especially within the adverse onboard conditions dimension. This overlap is due to a significant number of accidents that involved multiple adverse onboard conditions. For example, some of the accidents shown for system faults and failures also involved inappropriate crew response. Alternatively, many of the accidents shown for inappropriate crew response also involved other adverse onboard conditions, such as vehicle impairment, failure, or damage. Some of this overlap (especially for the largest number of accidents and fatalities) is identified in Figure 3. While there is some overlap in the external hazards and disturbances and the vehicle upset dimensions, it is generally much smaller that the onboard dimension. 


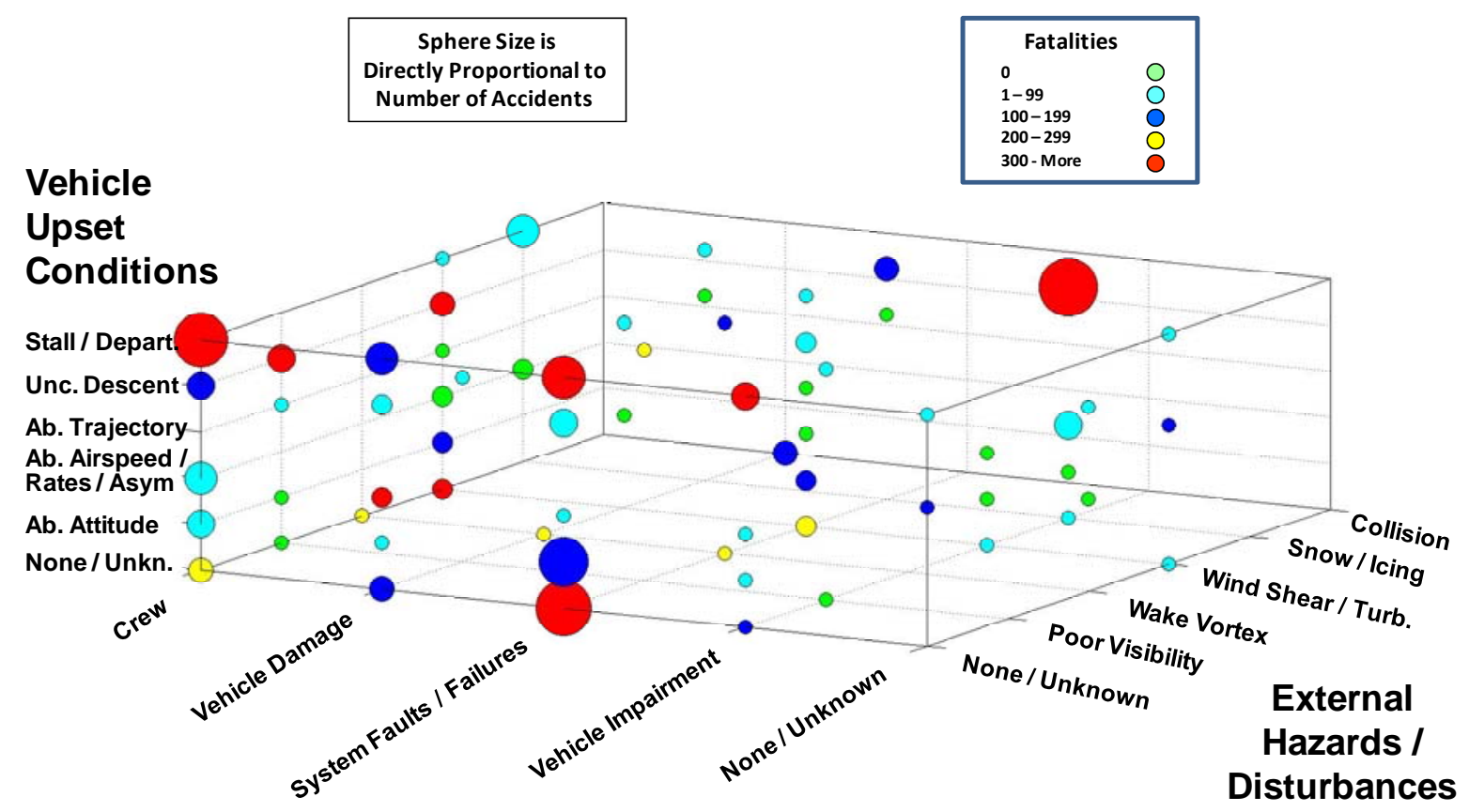

\section{Adverse Onboard Conditions}

Figure 2. Combinations of LOC Causal and Contributing Factors, 1979 - 2009.

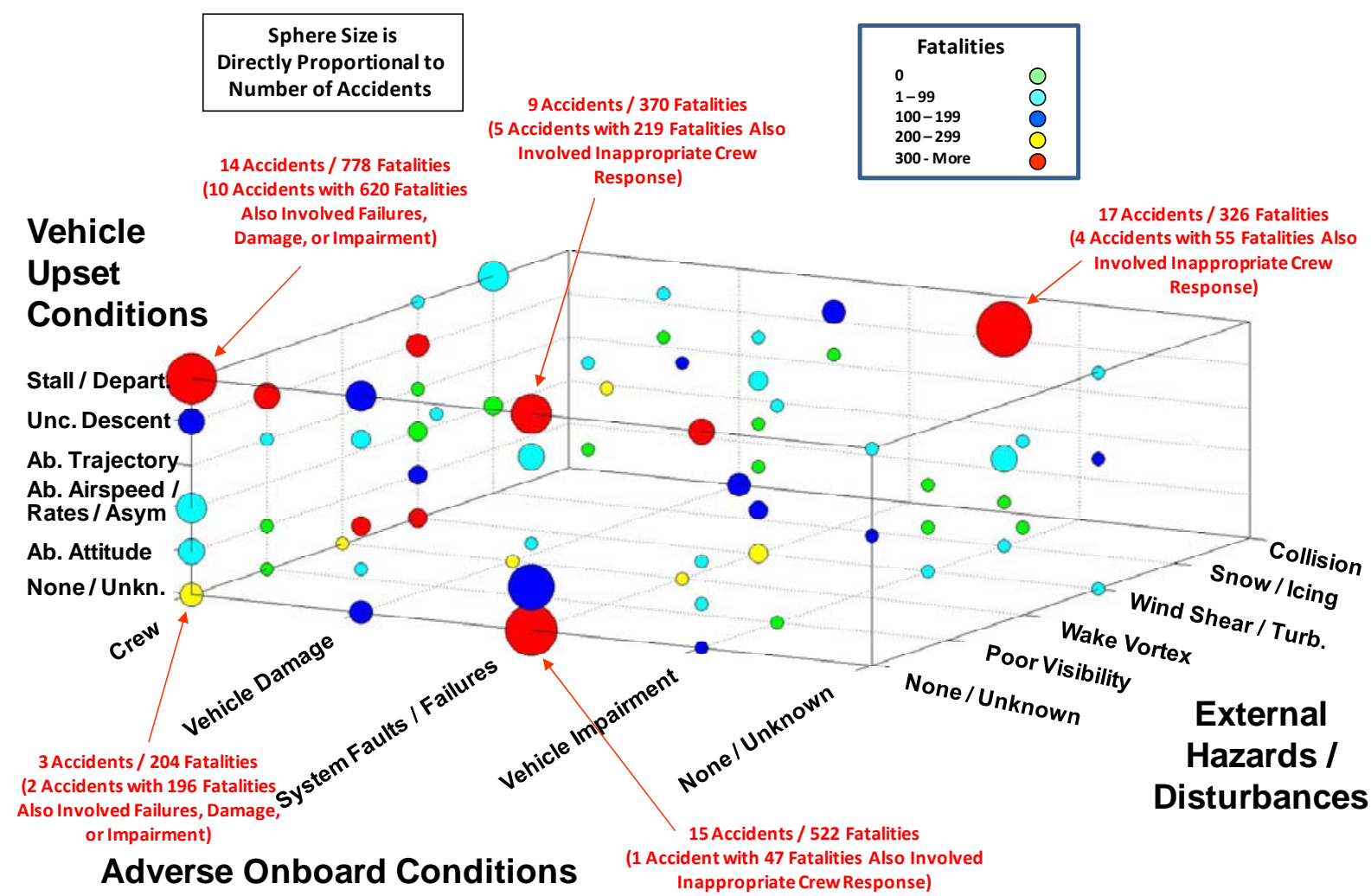

Figure 3. Identification of Overlap in LOC Causal and Contributing Factor Combinations, 1979 - 2009.

5

American Institute of Aeronautics and Astronautics 
Figures 2 and 3 are based on the set of 126 accidents over the 30 year period analyzed in this study. It could be argued that some of the factors associated with accidents that occurred longer ago than 15 years could have already been resolved. While only 35 accidents in this data set occurred more than 15 years ago (i.e., between 1979 and 1994), this potential effect was considered by removing them in the scatter plot of Figure 4 . As indicated in the figure, only minor differences are readily apparent. Some of these include: a lower number of fatalities for icing with vehicle impairment, and a lower number of accidents and fatalities associated with vehicle damage.

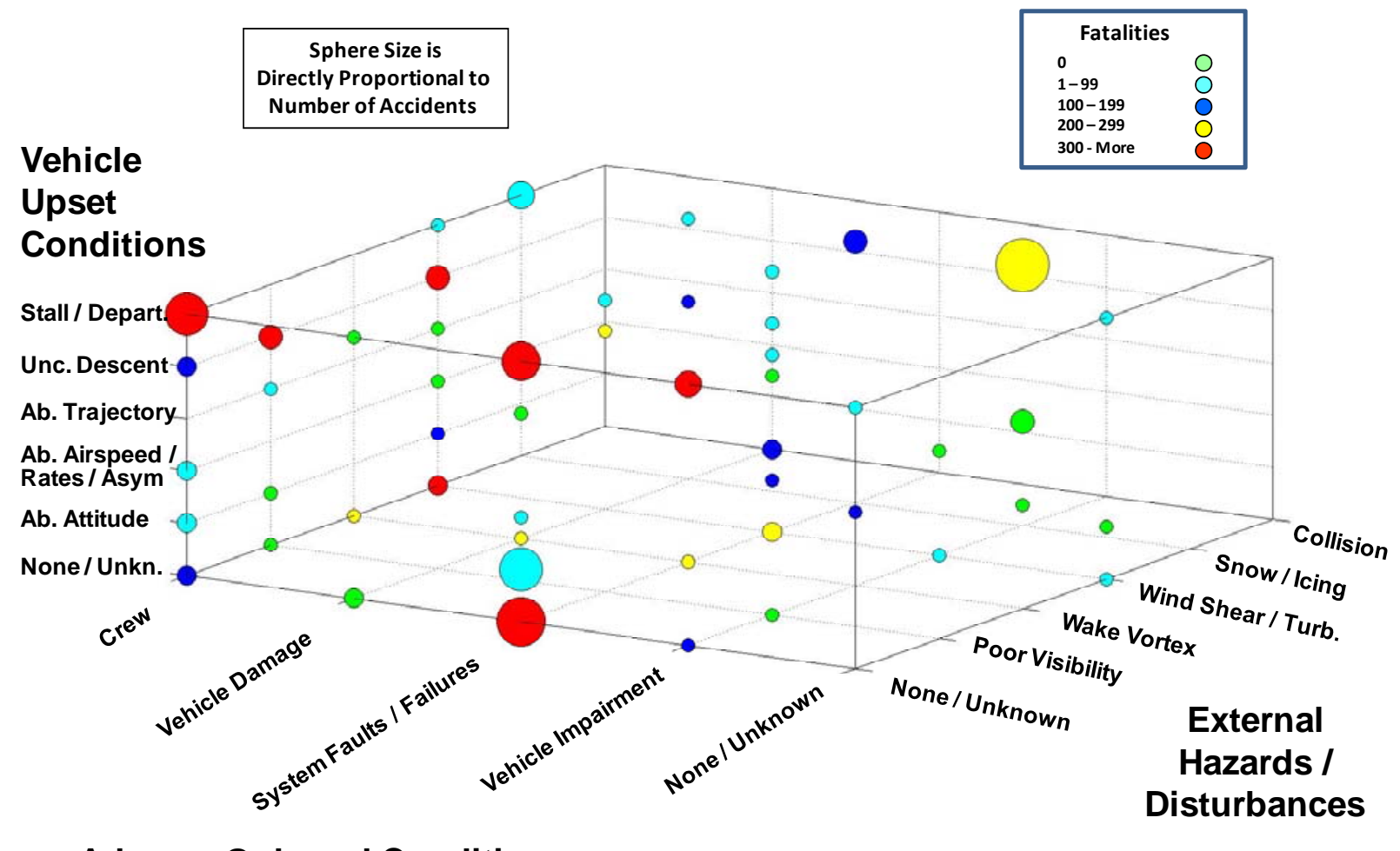

Adverse Onboard Conditions

Figure 4. Combinations of LOC Causal and Contributing Factors, 1994 - 2009.

It is also of interest to consider LOC accidents that resulted in no fatalities. These accidents might be an indicator of conditions that were recoverable or of emerging trends leading to LOC fatal accident increases. Figures 5 and 6 show these plots for the 30 year and 15 year data, respectively. 


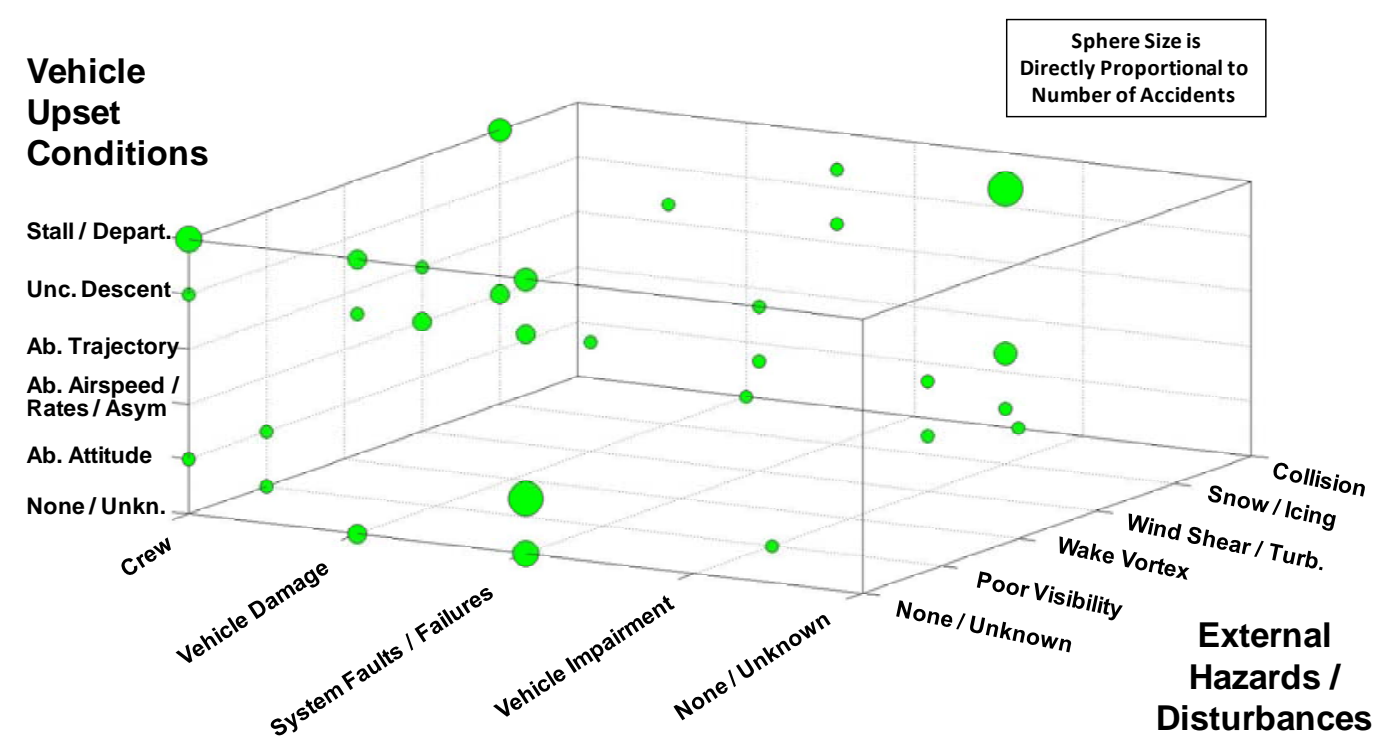

Adverse Onboard Conditions

Figure 5. Combinations of LOC Causal and Contributing Factors for Nonfatal Accidents, 1979 - 2009.

The results of Figures 5 and 6 are very similar. This similarity indicates that many of the nonfatal accidents in the data set occurred during the more recent 15 year period $(1994-2009)$. The largest numbers of nonfatal accidents were associated with failures (with and without upsets), vehicle damage (without upsets), icing and the associated vehicle impairment (with upsets), and inappropriate crew response combined with upsets (with and without wind shear / turbulence and icing conditions). It is not clear, however, whether these nonfatal accidents can be interpreted as emerging trends or simply as individual situations in which the crew was able to successfully recover. The latter might be assumed in this case, since there were also many accidents and fatalities associated with these conditions.

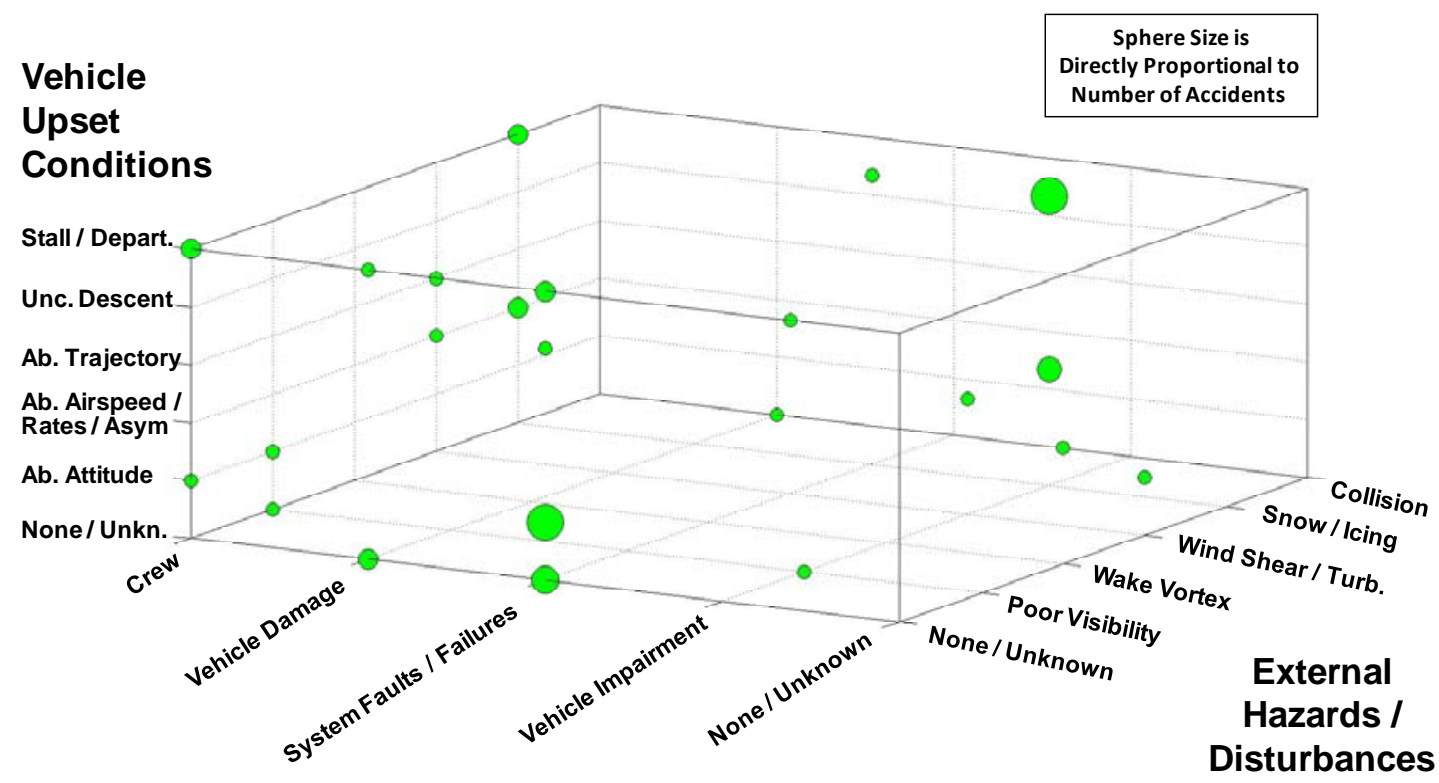

Adverse Onboard Conditions

Figure 6. Combinations of LOC Causal and Contributing Factors for Nonfatal Accidents, 1994 - 2009. 


\section{B. Analysis of Causal and Contributing Factor Sequences}

An analysis of the time sequencing of the LOC causal and contributing factors was performed for the 30-year data set. Table 2 provides a summary of this sequencing.

Table 2. Sequencing of LOC Accidents Causal and Contributing Factors

\begin{tabular}{|c|c|c|c|c|c|}
\hline Factor & 1st & 2nd & 3rd & 4th & 5th \\
\hline Adverse Onboard Conditions & 69 & 69 & 24 & 6 & 0 \\
\hline Vehicle Impairment & 3 & 29 & 3 & 0 & 0 \\
\hline System Faults / Failures / Errors & 42 & 11 & 4 & 0 & 0 \\
\hline Vehicle Damage & 6 & 7 & 5 & 5 & 0 \\
\hline Inappropriate Crew Response & 18 & 22 & 12 & 1 & 0 \\
\hline External Hazards \& Disturbances & 54 & 6 & $\mathbf{0}$ & $\mathbf{0}$ & 0 \\
\hline Poor Visibility & 7 & 0 & 0 & 0 & 0 \\
\hline Wake Vortices & 3 & 1 & 0 & 0 & 0 \\
\hline Wind Shear / Gusts / Thunderstorms & 14 & 3 & 0 & 0 & 0 \\
\hline Snow / Icing & 27 & 1 & 0 & 0 & 0 \\
\hline Abrupt Maneuver / Collision & 3 & 1 & 0 & 0 & 0 \\
\hline Vehicle Upsets & 3 & 36 & 47 & 15 & 1 \\
\hline Abnormal Attitude & 0 & 12 & 3 & 3 & 0 \\
\hline $\begin{array}{r}\text { Abnormal Airspeed / Angular Rates / } \\
\text { Asymmetric Forces }\end{array}$ & 0 & 3 & 7 & 4 & 0 \\
\hline Abnormal Flight Trajectory & 1 & 1 & 3 & 1 & 0 \\
\hline Uncontrolled Descent & 0 & 5 & 7 & 2 & 1 \\
\hline Stall / Departure & 2 & 15 & 27 & 5 & 0 \\
\hline
\end{tabular}

It should be noted that these sequences were identified without overlap. That is, there is no "double bookkeeping" of sequences in Table 2. Thus, the total number of initiating factors under column 1 sums to the total number of LOC accidents, since all LOC accidents result from at least 1 causal or contributing factor. Table 2 indicates that LOC events are usually first precipitated by an adverse onboard condition or an external hazard or disturbance. Moreover, external hazards and disturbances rarely occur further downstream in LOC sequences. Vehicle upsets are rarely the initial factor but rather an outcome of an external hazard or adverse onboard condition. Within adverse onboard conditions, system faults, failures, and errors are the leading initial factor, and inappropriate crew response is the second most likely initial event. Relative to external hazards and disturbances, the leading initial factor is icing, followed by wind shear, gusts, and thunderstorms. Adverse onboard conditions are also the most likely factor to occur second in the chain of events leading to aircraft LOC, with vehicle impairment being the most likely secondary factor to occur. This is due to vehicle impairment resulting from icing conditions (i.e., contaminated airfoil or reduced engine performance), faults or damage. Vehicle upsets most often occur as the second, third, or fourth factor in the LOC sequence. Only one 5 -factor sequence was identified in this data set.

An analysis was also performed of each LOC sequence. This analysis is summarized in Table 3 and detailed in Figures 7 - 16. Table 3 provides the number of accidents and fatalities (and associated percentages) relative to each causal and contributing factor as the initial factor in the LOC sequence. Defining the LOC sequences in terms of the initiating factor allowed a comprehensive assessment without overlap. 
Table 3. Summary of LOC Accident Sequences

\begin{tabular}{|c|c|c|c|c|c|}
\hline Initial Factor in LOC Sequence & Accidents & $\%$ & Fatalities & $\%$ & Figures \\
\hline Adverse Onboard Conditions & 69 & 54.8 & 3733 & 61.3 & $7-10$ \\
\hline Vehicle Impairment & 3 & 2.4 & 186 & 3.1 & 7 \\
\hline System Faults / Failures / Errors & 42 & 33.3 & 1544 & 29.0 & 8 \\
\hline Vehicle Damage & 6 & 4.8 & 908 & 14.9 & 9 \\
\hline Inappropriate Crew Response & 18 & 14.3 & 1095 & 14.3 & 10 \\
\hline External Hazards \& Disturbances & 54 & 42.8 & 2228 & 36.6 & 11-15 \\
\hline Poor Visibility & 7 & 5.5 & 438 & 7.2 & 11 \\
\hline Wake Vortices & 3 & 2.4 & 137 & 2.2 & 12 \\
\hline Wind Shear / Gusts / Thunderstorms & 14 & 11.1 & 874 & 14.4 & 13 \\
\hline Snow / Icing & 27 & 21.4 & 590 & 9.7 & 14 \\
\hline Abrupt Maneuver / Collision & 3 & 2.4 & 189 & 3.1 & 15 \\
\hline Vehicle Upsets & 3 & 2.4 & 126 & 2.1 & 16 \\
\hline Abnormal Attitude & 0 & 0 & 0 & 0 & - \\
\hline $\begin{array}{r}\text { Abnormal Airspeed / Angular Rates / } \\
\text { Asymmetric Forces }\end{array}$ & 0 & 0 & 0 & 0 & - \\
\hline Abnormal Flight Trajectory & 1 & 0.8 & 117 & 1.9 & 16 \\
\hline Uncontrolled Descent & 0 & 0 & 0 & 0 & 16 \\
\hline Stall / Departure & 2 & 1.6 & 9 & 0.2 & 16 \\
\hline Totals & 126 & 100 & 6087 & 100 & $7-16$ \\
\hline
\end{tabular}

As indicated in Table 3, LOC events initiated by adverse onboard conditions comprised 54.8\% of the accidents and $61.3 \%$ of the fatalities within the data set considered in this analysis. Of these, system failures, faults, and errors initiated $33.3 \%$ of accidents and $29 \%$ of fatalities, followed by inappropriate crew response, vehicle damage, and vehicle impairment. External hazards and disturbances initiated $42.8 \%$ of the accidents and $36.6 \%$ of the fatalities in the LOC accidents considered. Within this category, icing represented $21.4 \%$ of accidents and $9.7 \%$ of fatalities, whereas wind shear, turbulence, and thunderstorms initiated $11.1 \%$ of accidents and $14.4 \%$ of fatalities. These factors were followed in frequency of occurrence by poor visibility, wake vortices, and abrupt maneuver or collision (with the last two having the same frequency of occurrence). It is interesting to note that icing initiated more accidents, but wind-related disturbances resulted in more fatalities. This is because the predominance of icinginduced accidents in the data set of this study involved smaller aircraft, whereas the preponderance of wind-induced accidents in this data set involved large transports. As indicated previously, vehicle upsets are rarely the precipitating factor in the LOC sequence, with these comprising $2.4 \%$ of the accidents and $2.1 \%$ of the fatalities considered in this study. Within this category, stall/departure initiated $1.6 \%$ of the accidents and $0.2 \%$ of fatalities, and abnormal flight trajectory initiated $0.8 \%$ of accidents and $1.9 \%$ of fatalities in the data set. While upsets are not usually the precipitating factor, many LOC sequences include vehicle upset somewhere in the chain of events (as indicated in Table 2). The last column of Table 3 references the figures that present the detailed LOC sequences associated with each initial factor. Sequences initiated by adverse onboard conditions are provided in Figures 7 - 10, those initiated by external hazards and disturbances are shown in Figures $11-15$, and Figure 16 provides the sequences initiated by vehicle upsets. Each figure lists the LOC sequence number on the left, and the accident identification number from the Appendix is identified on the right in parentheses. The number of accidents and fatalities associated with each sequence is also provided.

Figure 7 shows the 5 LOC sequences initiated by vehicle impairment, with the associated number of accidents and fatalities provided for each sequence. The initiating events for these accidents included: aircraft overweight (1 accident that was overloaded with passengers), inappropriate vehicle configuration (1 accident), and an emulated engine failure during a training flight (1 accident). As indicated in Figure 7, 33\% of these LOC sequences culminated in a vehicle upset, and 33\% involved an inappropriate crew action or response. 
Vehicle Impairment: 3 Accidents, 186 Fatalities:

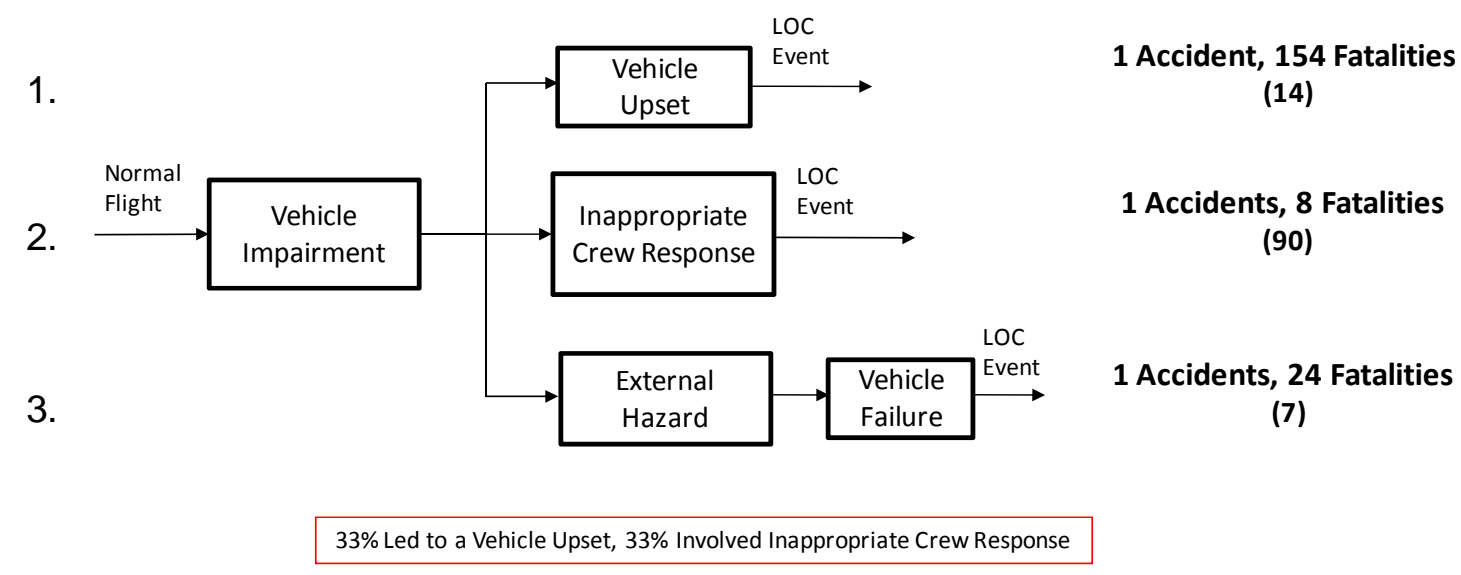

Figure 7. LOC Accident Sequences Initiated by Vehicle Impairment.

Figure 8 shows the 42 LOC sequences initiated by system failures. The initiating events for these accidents included: engine and engine control failures (17 accidents), flight control sensors and instrumentation failures and malfunctions (9 accidents), flight control system and component design errors and failures (15 accidents), and flight deck warning system failures (1 accident). External hazards and disturbances associated with these sequences included turbulence ( 2 accidents), wake vortices ( 1 accident), and an external obstruction (1 accident). As indicated in Figure $8,26 \%$ of these sequences involved only the failure condition, 57\% of these sequences led to vehicle upset, and 26\% involved inappropriate crew response. All types of vehicle upsets (i.e., abnormal attitude; abnormal airspeed, angular rates, or asymmetric forces; abnormal flight trajectory; uncontrolled descent; and stall/departure) occurred in these LOC sequences.

Figure 9 shows the 11 LOC sequences initiated by vehicle damage. The precipitating damage events in these sequences included airframe structural damage ( 5 accidents) and engine damage ( 1 accident involving fatigue cracks in the engine). As indicated in Figure 9, 83\% of these sequences culminated in vehicle upset, and only 1 sequence involved inappropriate crew response. 
Vehicle Failure: 42 Accidents, 1767 Fatalities:
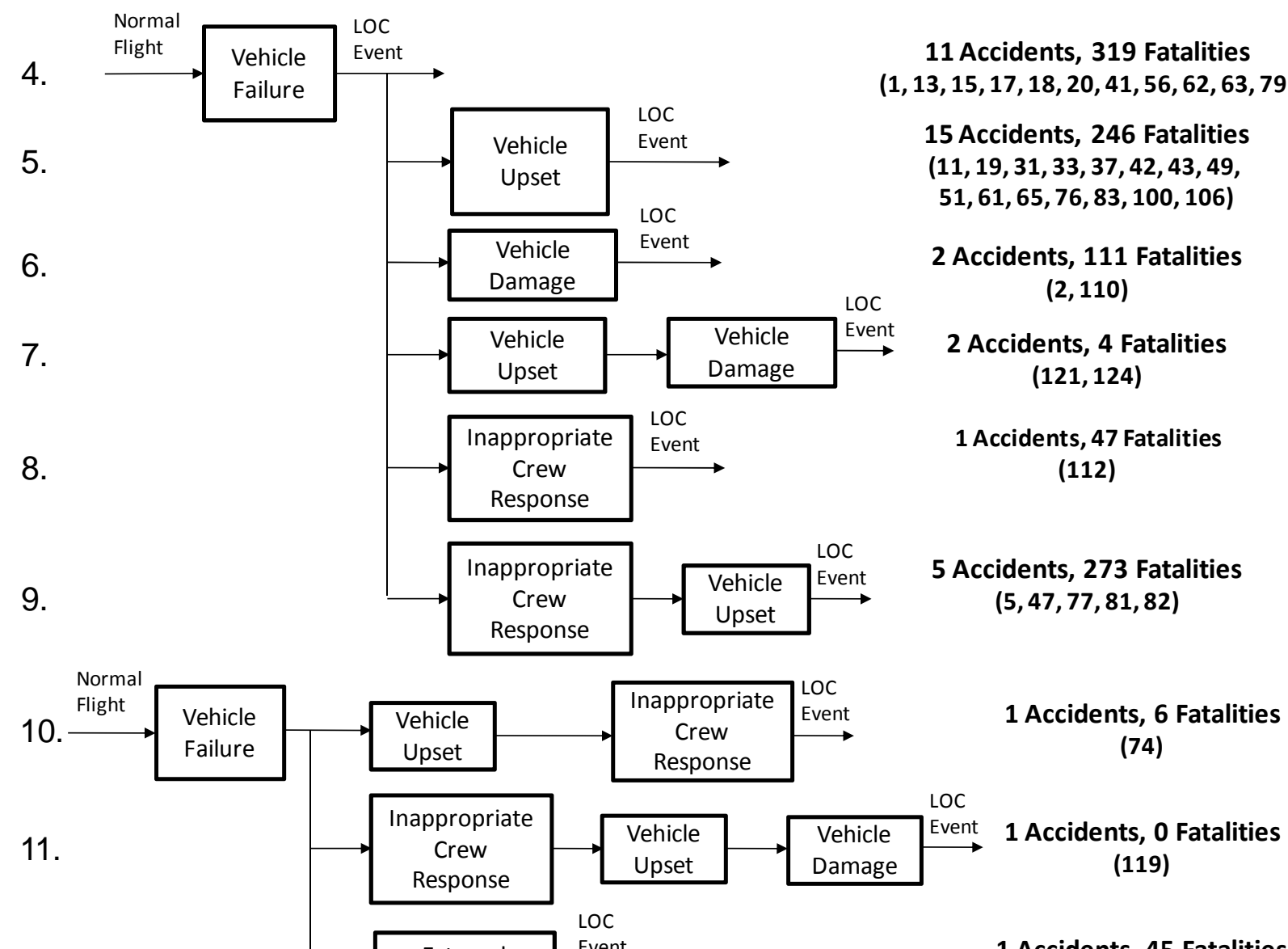

12.

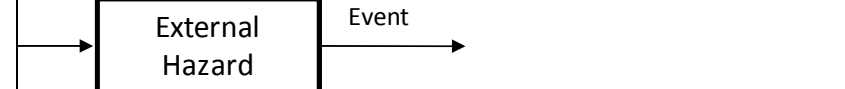

1 Accidents, 45 Fatalities

(25)

13.

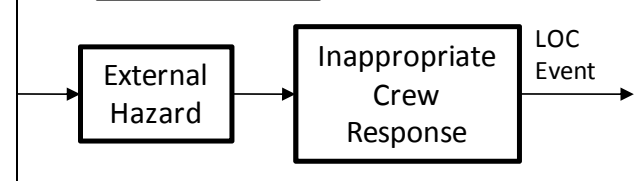

1 Accidents, 228 Fatalities

(4)

14.

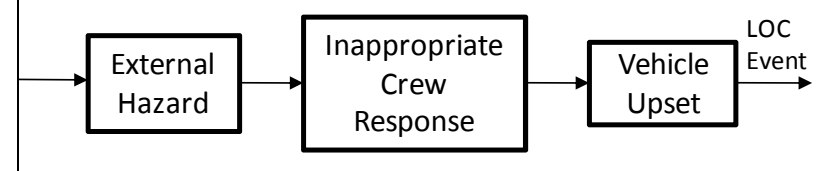

1 Accidents, 0 Fatalities

(58)

15.

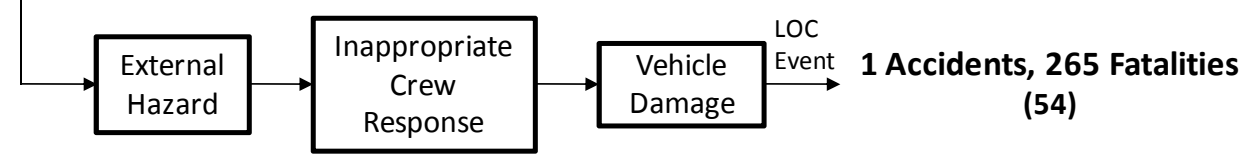

57\% Led to a Vehicle Upset, 26\% Involved Failure Only, 26\% Involved Inappropriate Crew Response

Figure 8. LOC Accident Sequences Initiated by Failures. 
Vehicle Damage: 6 Accidents, 908 Fatalities:

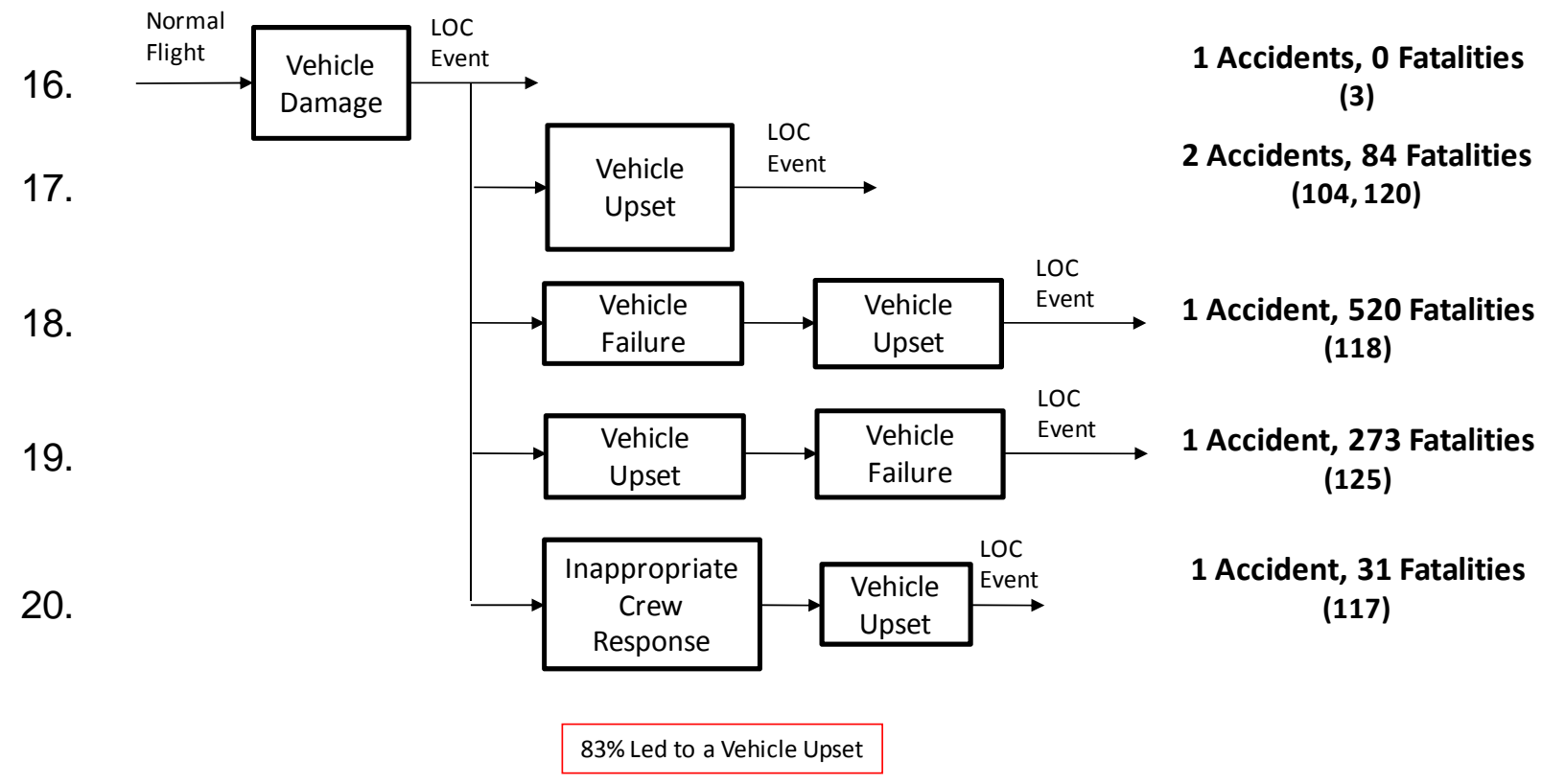

Figure 9. LOC Accident Sequences Initiated by Damage.

Figure 10 shows the 18 LOC sequences initiated by inappropriate crew actions. These actions included: improper and inadvertent control inputs (9 accidents), crew impairment and distraction (3 accidents), spatial disorientation (2 accidents), failure to configure the vehicle properly (3 accidents), and improper pre-flight planning or preparation (1 accident). As indicated in Figure 10,100\% of these sequences led to an upset condition, and $50 \%$ resulted in vehicle impairment or damage.

Figures 11-15 show the LOC sequences that were initiated by external hazards and disturbances. Figure 11 shows the 7 sequences precipitated by poor visibility. As indicated in the figure, $86 \%$ of these sequences culminated in a vehicle upset condition, and 86\% involved inappropriate crew response. Of the 6 sequences involving inappropriate crew response, 5 resulted from spatial disorientation. Figure 12 shows the 3 LOC sequences initiated by a wake vortex encounter. All of these sequences culminated in a vehicle upset. Figure 13 shows the 14 LOC sequences initiated by wind shear, turbulence, and thunderstorms. As indicated in the figure, $86 \%$ of these sequences led to a vehicle upset condition, and 64\% involved inappropriate crew response. 
Inappropriate Crew Response: 18 Accidents, 1095 Fatalities:

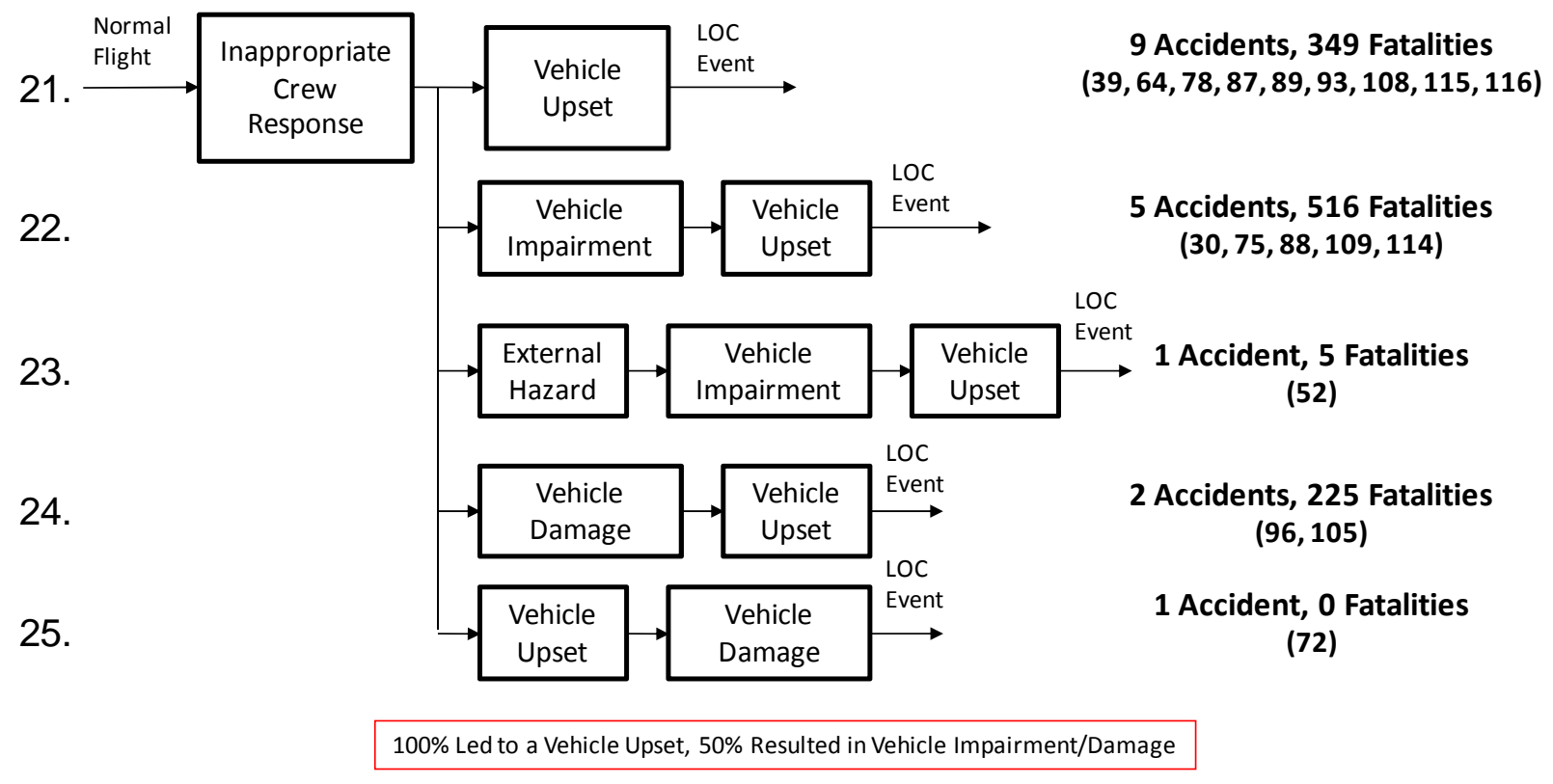

Figure 10. LOC Accident Sequences Initiated by Inappropriate Crew Input.

Poor Visibility: 7 Accidents, 438 Fatalities:

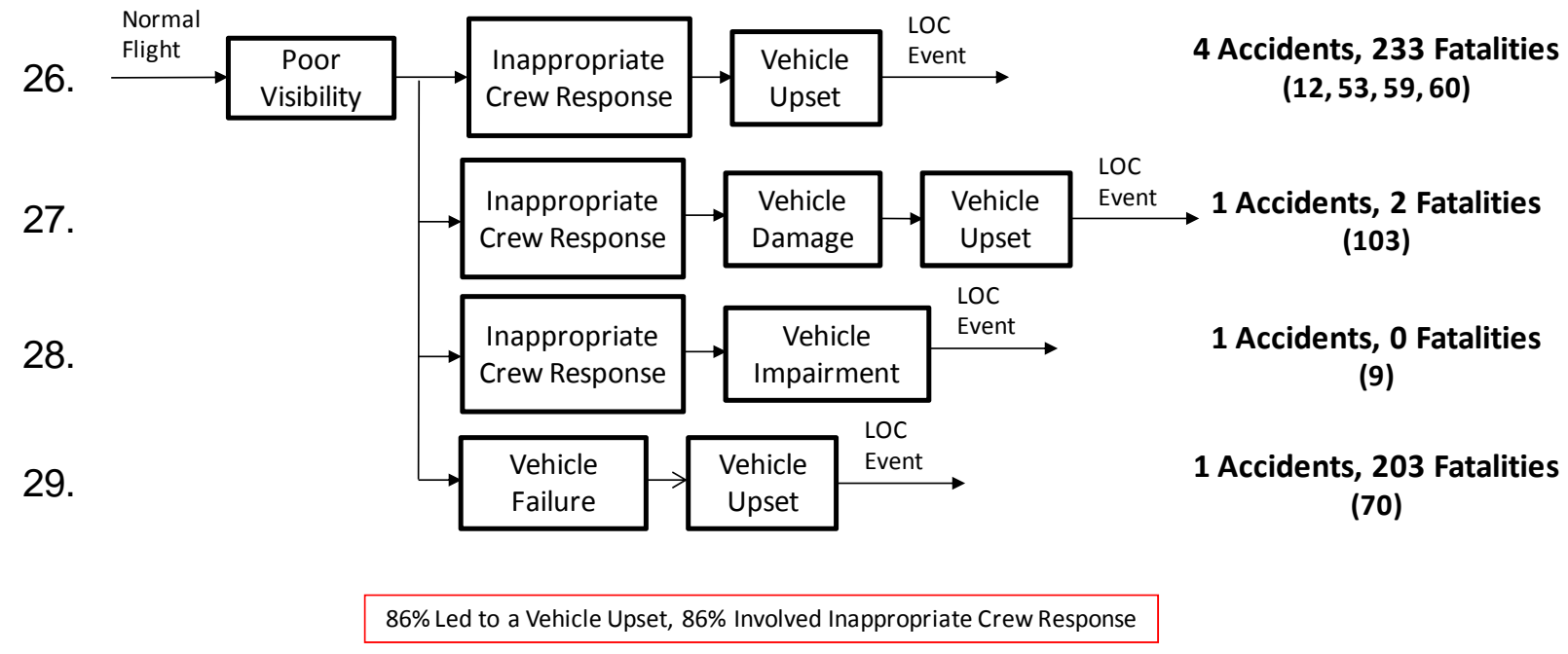

Figure 11. LOC Accident Sequences Initiated by Poor Visibility. 
Wake Vortex: 3 Accidents, 137 Fatalities:

30.

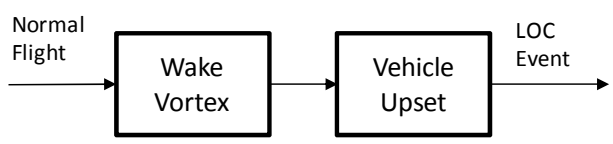

2 Accidents, 5 Fatalities

$(57,92)$

31.

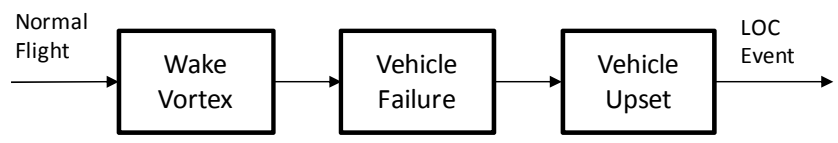

1 Accident, 132 Fatalities

(85)

$100 \%$ Led to a Vehicle Upset

Figure 12. LOC Accident Sequences Initiated by Wake Vortex Encounter.

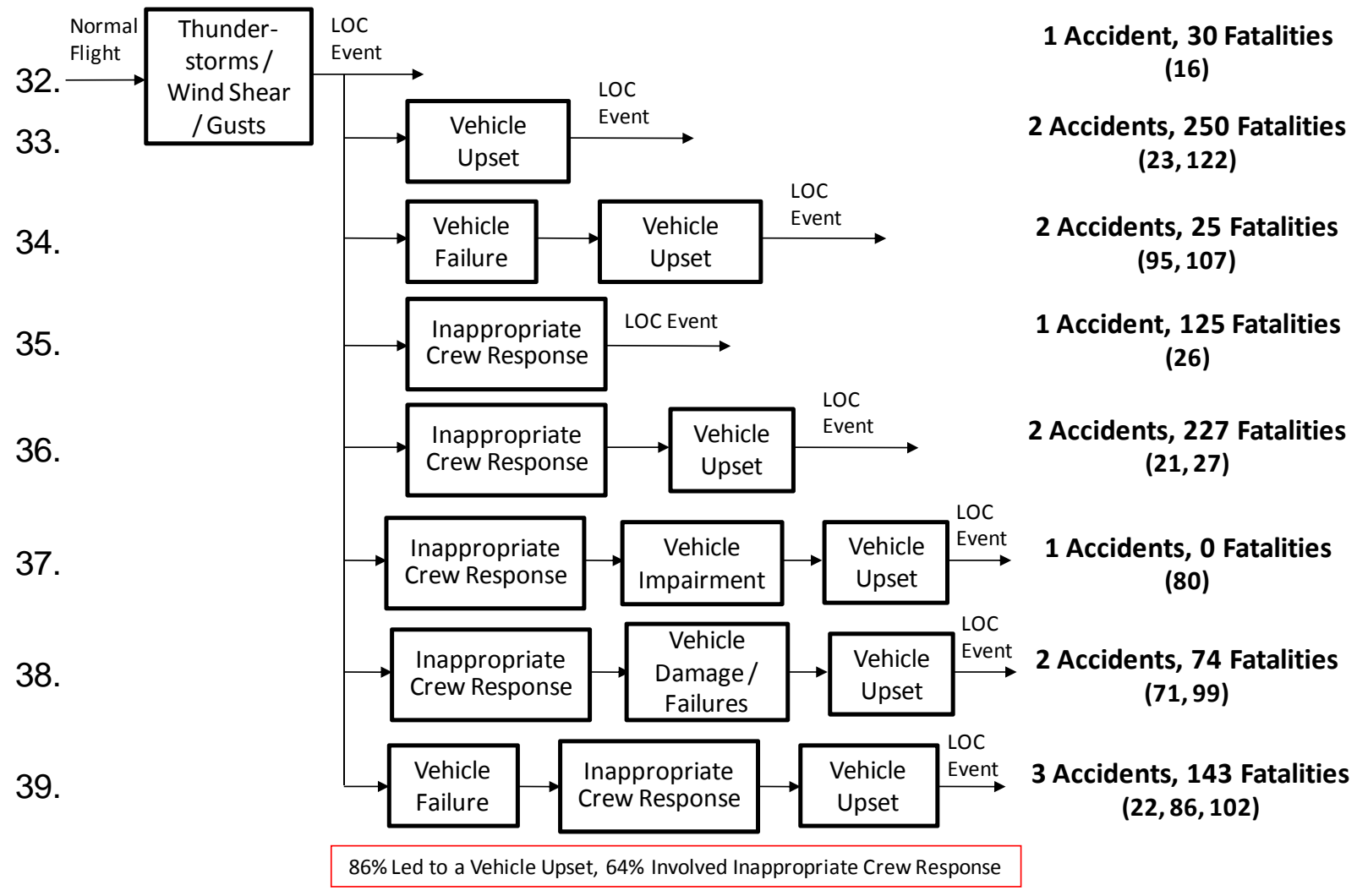

Figure 13. LOC Accident Sequences Initiated by Wind Shear, Gusts, \& Thunderstorms.

Figure 14 shows the 27 LOC sequences that were initiated by snow and icing conditions. As indicated in the figure, $10 \%$ of these sequences led to a vehicle upset, and $22 \%$ involved inappropriate crew response. 
Snow / Icing: 27 Accidents, 590 Fatalities:

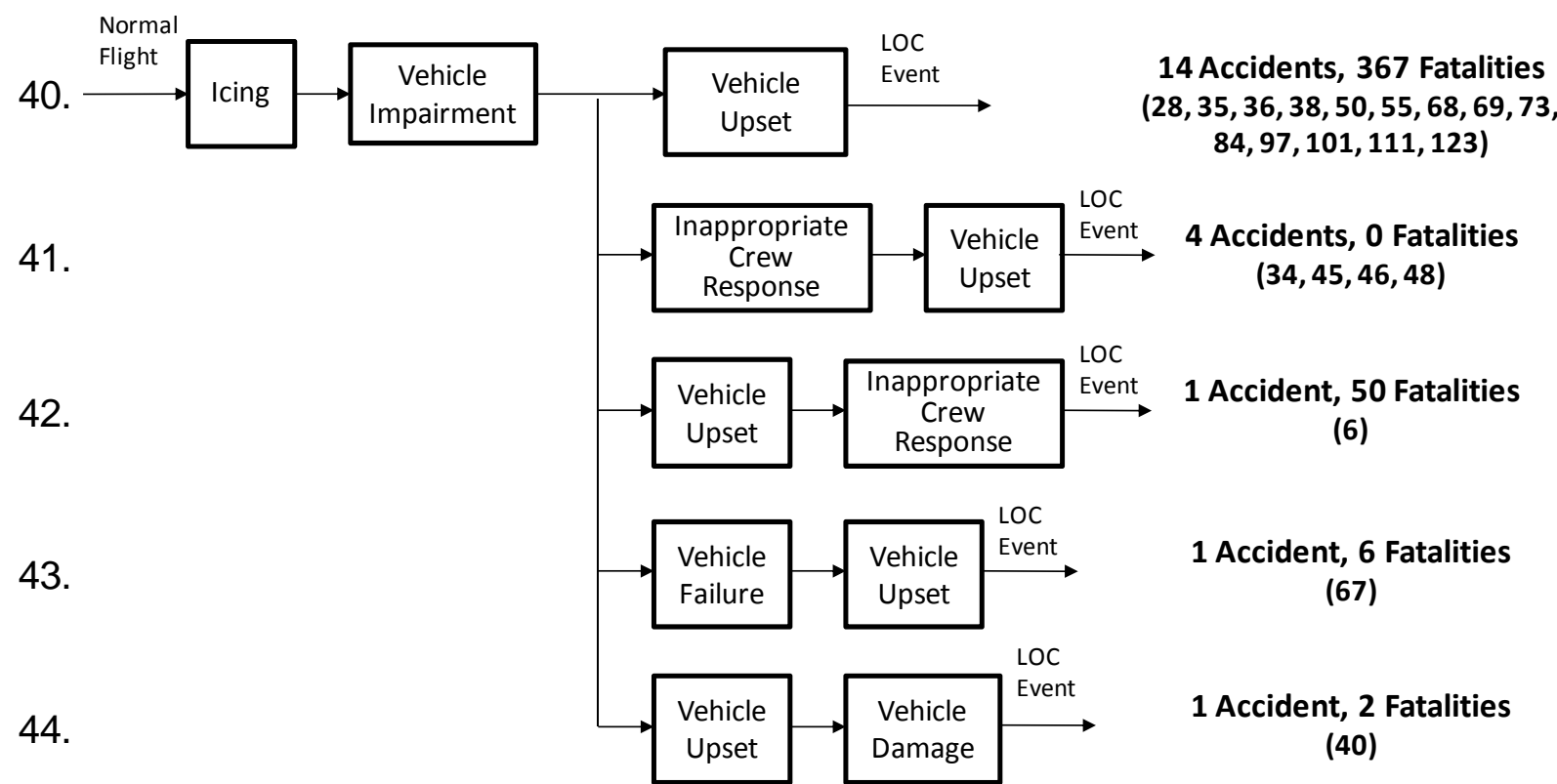

45.

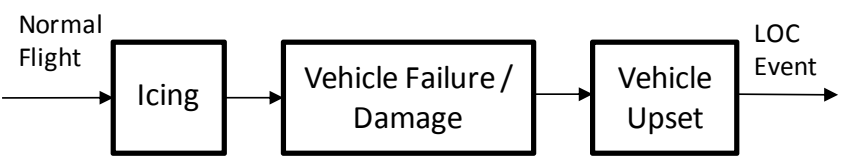

3 Accidents, 160 Fatalities

$(32,66,126)$

46.

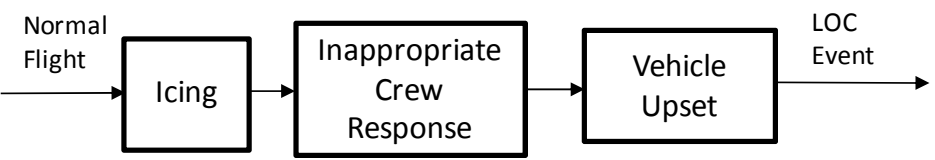

\section{Accident, 0 Fatalities}

(94)

1 Accident, 5 Fatalities

(91)

47.

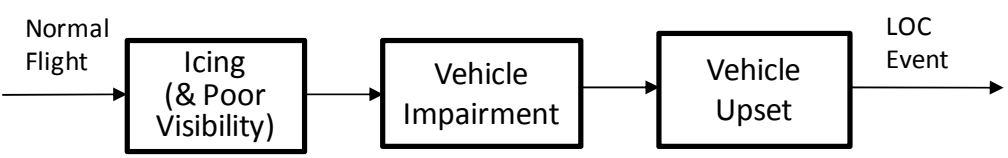

48.

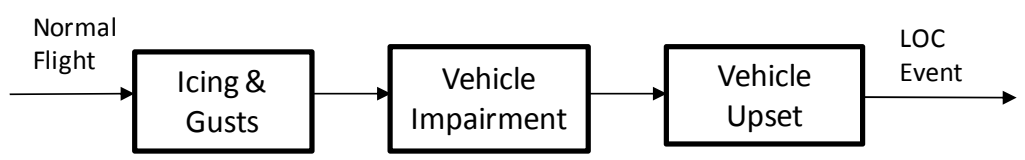

\section{Accident, 0 Fatalities}

(98)

$100 \%$ Led to a Vehicle Upset, 22\% Involved Inappropriate Crew Response

Figure 14. LOC Accident Sequences Initiated by Snow / Icing.

Figure 15 shows the 3 LOC sequences that were initiated by abrupt maneuvers and collisions. All of these sequences were initiated by a mid-air collision ( 1 with another aircraft, and 2 with a flock of birds). 
Abrupt Maneuver / Collision: 3 Accidents, 189 Fatalities:

49.

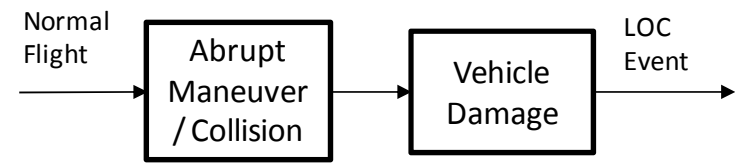

\section{Accidents, 189 Fatalities}

$(8,24,113)$

Figure 15. LOC Accident Sequences Initiated by Abrupt Maneuver / Collision.

Figure 16 shows the 7 LOC sequences initiated by vehicle upsets. The precipitating event for these upsets was undetermined. The last accident associated with Sequence 52 occurred during a low-speed check to activate the alpha floor protection system following maintenance. In this accident, the aircraft stalled on approach and recovery was impaired by the vehicle being configured inappropriately for go-around. It is unclear at this time whether the initial stall condition resulted from incorrect or inappropriate flight procedures or an error in the flight control system.

Abnormal Flight Trajectory: 1 Accident, 117 Fatalities:

50.

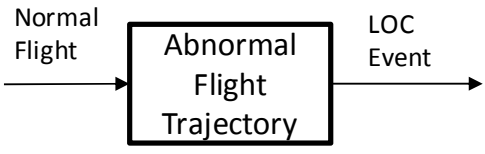

1 Accident, 117 Fatalities

(29)

Stall / Departure: 2 Accidents, 9 Fatalities:

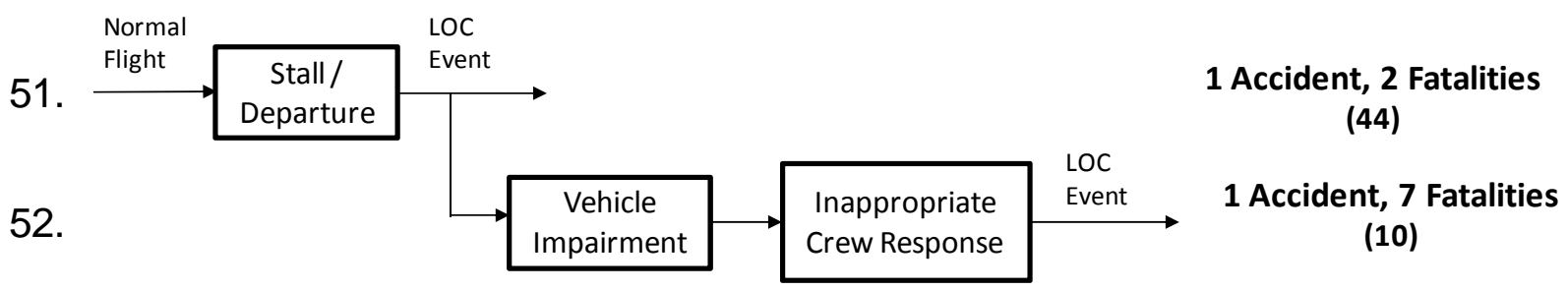

Figure 16. LOC Accident Sequences Initiated by Vehicle Upsets.

In order to condense the LOC sequences of Figures 7-16 into smaller, more actionable groupings, these sequences can be combined and generalized. In an effort to represent a large majority of the sequences identified in this study. Figure 17 shows the top 10 LOC combined sequences relative to number of accidents and fatalities. Dashed boxes represent factors that occurred in some subset within the sequence. As indicated in Figure 17, this top 10 set of combined LOC sequences represents $86.5 \%$ of the accidents and $89.1 \%$ of the fatalities considered in this study. This set can be further reduced by generalizing the sequences. Some generalized sequences are shown in Figure 18 along with the associated number of accidents and fatalities. These 7 generalized sequences represent 112 accidents (88.9\%) and 5529 fatalities (90.8\%). 


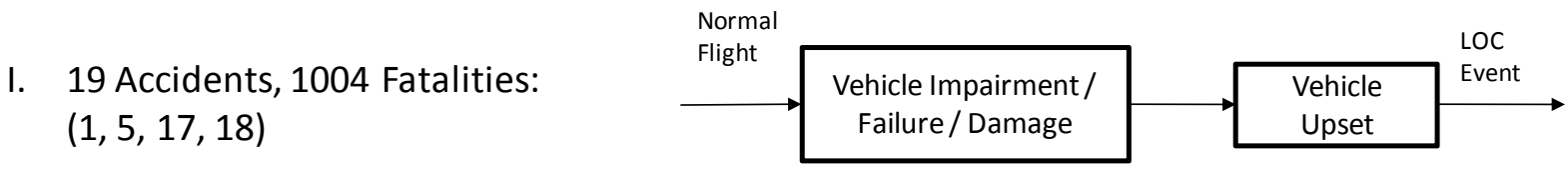

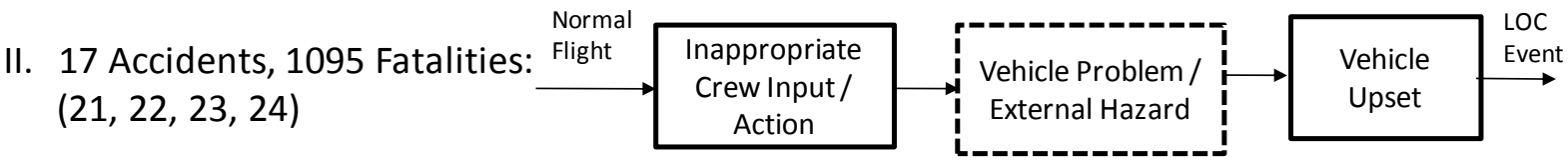

III. 24 Accidents, 851 Fatalities:

$(29,31,34,40,43,45,47,48)$

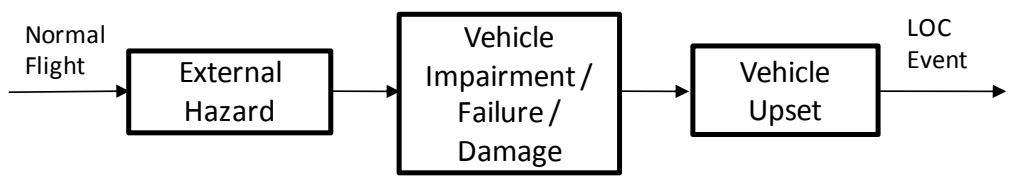

IV. 14 Accidents, 430 Fatalities:

$(4,6,16)$

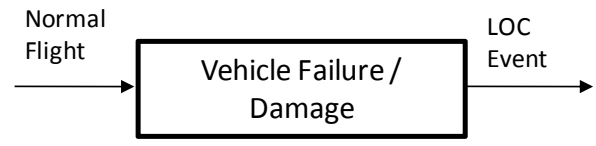

V. 7 Accidents, 460 Fatalities:

$(26,36,46)$

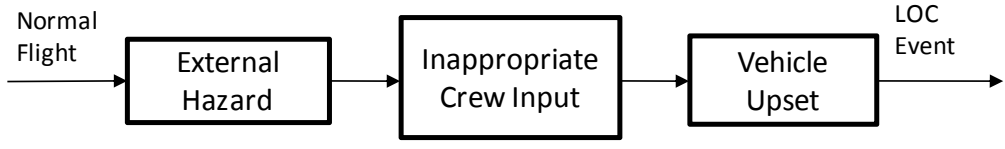

VI. 8 Accidents, 569 Fatalities: $(30,33,35,49)$

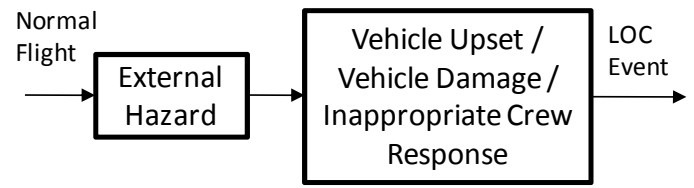

VII. 3 Accidents, 493 Fatalities: $\stackrel{\text { Flight }}{(13,14,15)} \longrightarrow \begin{aligned} & \text { Vehicle } \\ & \text { Failure }\end{aligned} \longrightarrow \begin{aligned} & \text { External } \\ & \text { Hazard }\end{aligned}$

VIII. 6 Accidents, 304 Fatalities: $(9,20)$

Normal

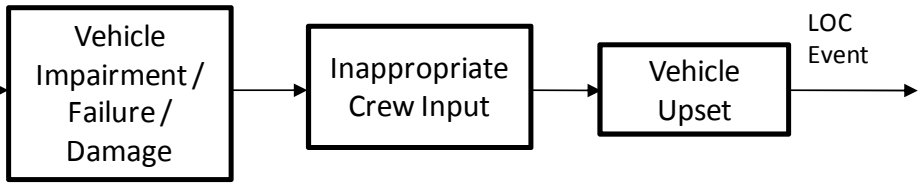

IX. 7 Accidents, 143 Fatalities: $(39,41)$

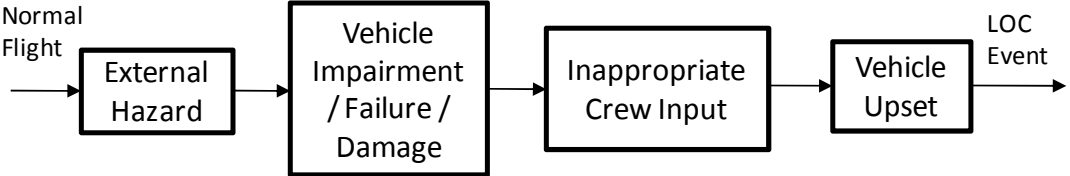

X. 4 Accidents, 76 Fatalities: $(27,37,38)$

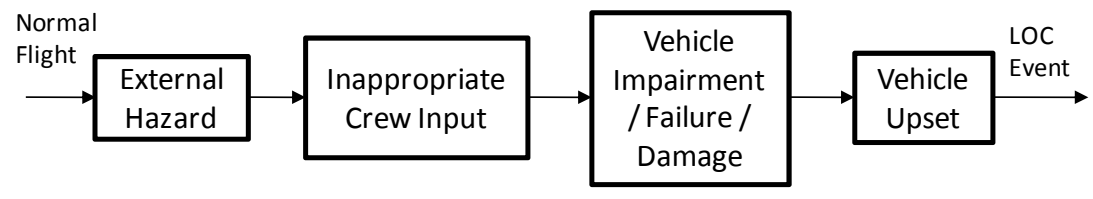

Top 10 Totals: 109 Accidents (86.5\%), 5425 (89.1\%)

Figure 17. Top 10 LOC Accident Sequences.

17

American Institute of Aeronautics and Astronautics 
A. 43 Accidents, 1855 Fatalities: (I, III)

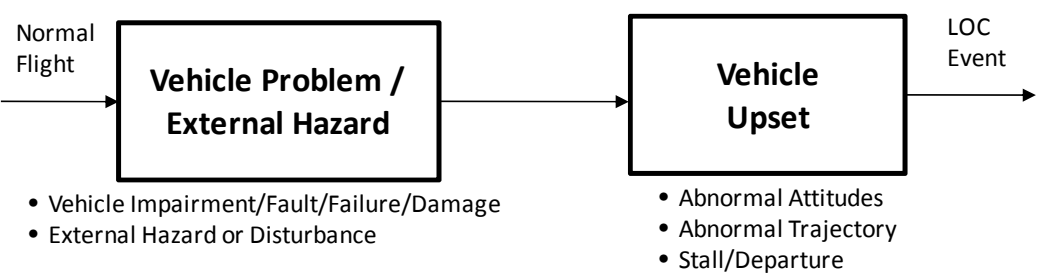

B. 20 Accidents, 907 Fatalities: (V, VIII, IX)

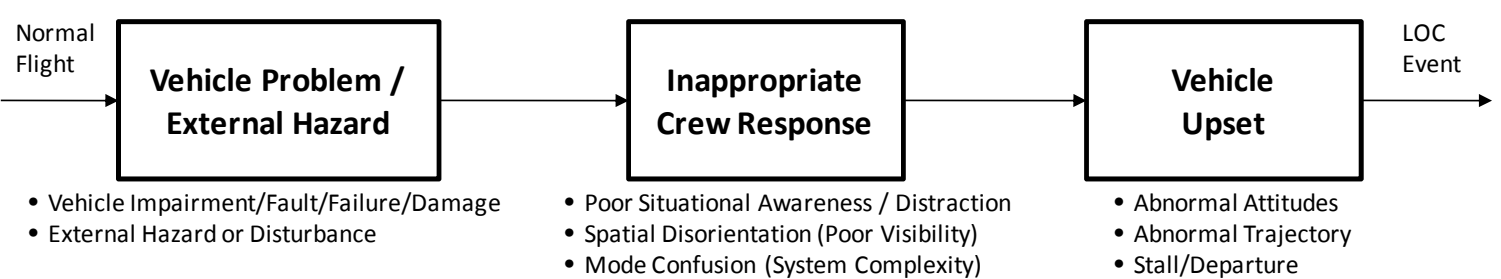

C. 17 Accidents, 1095 Fatalities: (II)

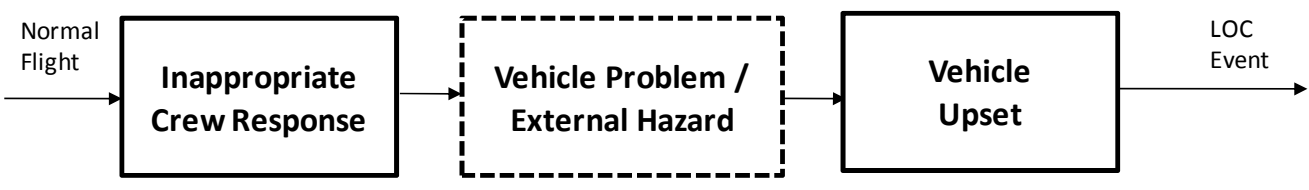

D. 16 Accidents, 484 Fatalities: (IV, 3, 32)

E. 8 Accidents, 569 Fatalities: (VI)
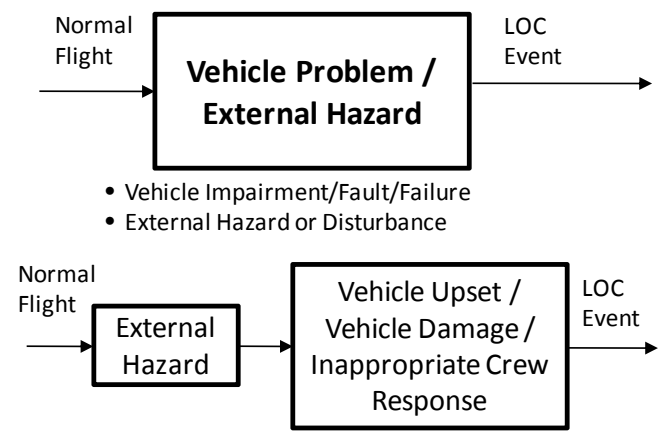

F. 7 Accidents, 569 Fatalities: (VII, X)

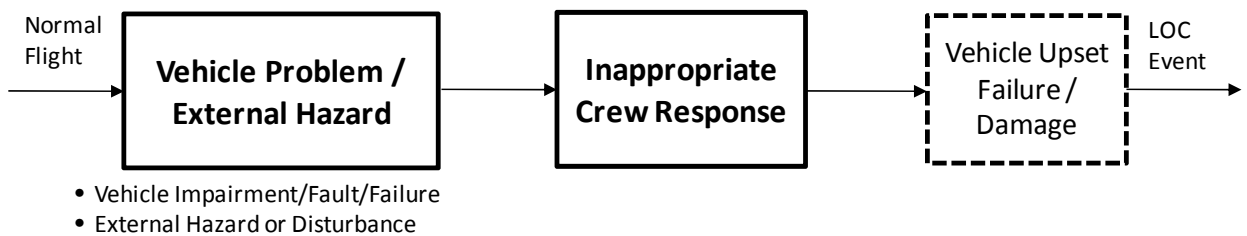

G. 1 Accident, 50 Fatalities: (42)

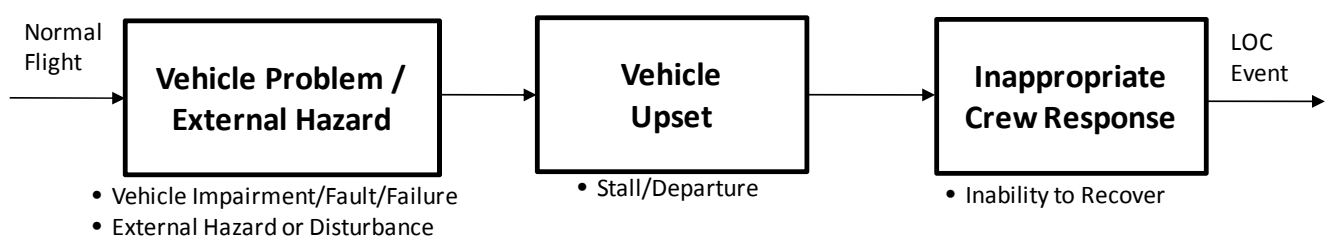

Figure 18. Generalized LOC Accident Sequences.

American Institute of Aeronautics and Astronautics 


\section{Future Considerations}

In addition to looking at historical accident data, potential future LOC accident risks should be identified relative to known (as well as new) precursors. This is more difficult, because (without data) it becomes more speculative. However, the identification of potential future risks might enable the development of a comprehensive intervention strategy that anticipates and mitigates these future potential risks. One area of consideration is airspace operation under the Next Generation (NextGen) Air Transportation System. ${ }^{7}$ The NextGen concept of operations provides an integrated view of airspace operations in the 2025 timeframe and includes high-density, all-weather, and selfseparation operational concepts. There is also expected to be mixed-capability aircraft operating within the same airspace, including piloted aircraft and unmanned aircraft systems. High-precision 4-D trajectories are envisioned that will enable safely flying with closer spacing to inclement weather, terrain, and other aircraft, and these trajectories can be altered if necessary during the flight. Other areas of consideration include increasing airspace and vehicle system complexity without developing comprehensive methods for their validation and verification $(\mathrm{V} \& \mathrm{~V})$, and increased automation without improved crew interfaces.

In an effort to identify areas of potential future LOC risk in terms of known precursors, Figure 19 illustrates several areas of possible increase in causal and contributing factors with the potential for increased LOC accidents or incidents. If all-weather operations and highly precise trajectories that enable closer spacing to inclement weather increase the probability of an aircraft actually encountering inclement weather during flight, this could result in a larger number of weather-related LOC accidents (particularly in the terminal area). If airspace and vehicle system complexity is increased without comprehensive methods for their $\mathrm{V} \& \mathrm{~V}$, this could lead to a larger number of LOC events initiated by system faults, failures, and errors. If high-density mixed-vehicle operations and high-precision tracking that enables closer spacing between aircraft increase the probability of aircraft encountering other aircraft during flight, this could result in a larger incidence of wake-induced LOC events or ultimately those initiated by vehicle damage resulting from mid-air collisions. Increased automation without improved crew interfaces could result in a higher incidence of LOC events precipitated by inappropriate crew actions.

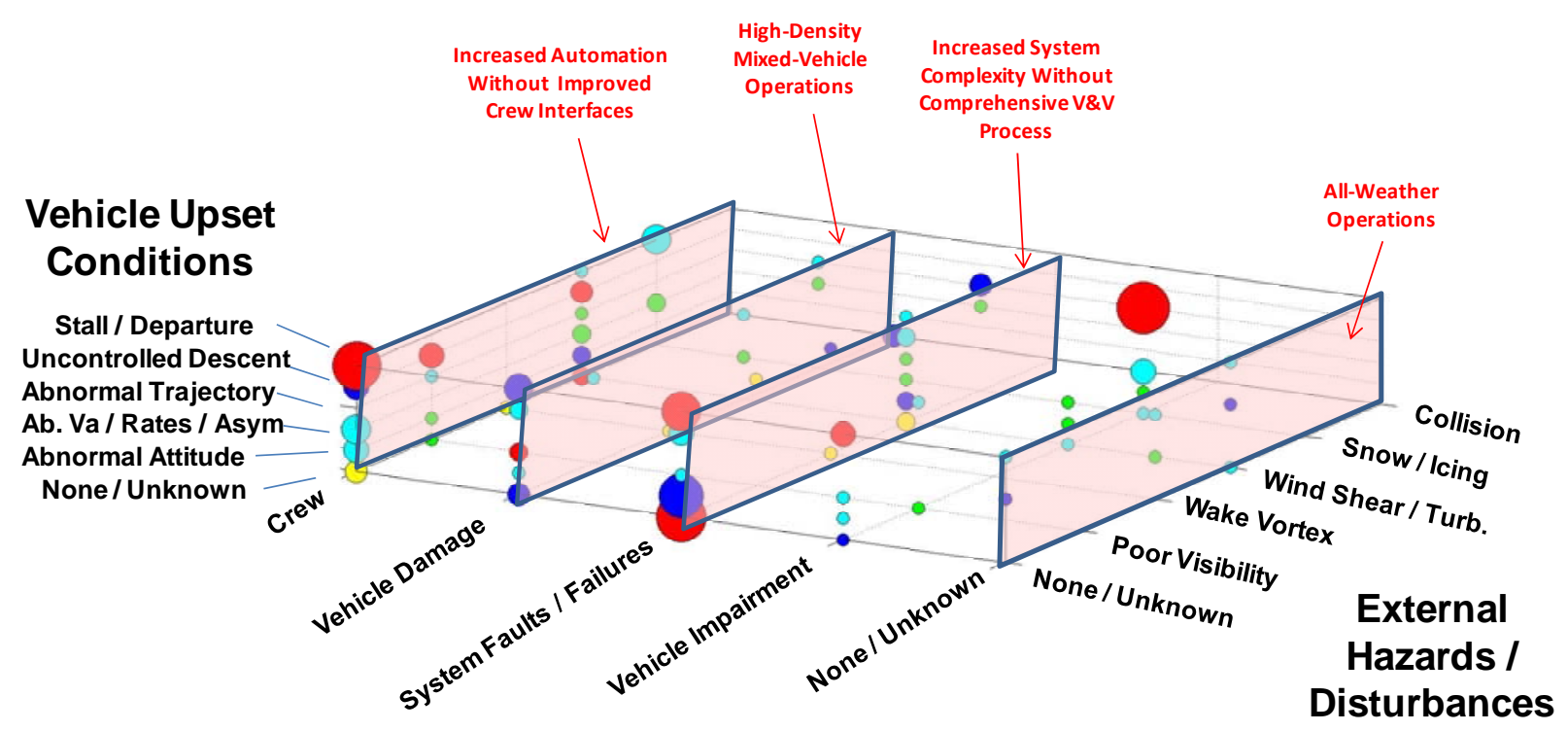

\section{Adverse Onboard Conditions}

Figure 19. Potential Areas of Future Increased LOC Risk.

In order to consider LOC sequences that could become more prevalent under NextGen, Figure 20 shows summarized sequences grouped by relevance to NextGen operations. High-density operations are represented by LOC sequences that were initiated by wake vortex encounters or mid-air collisions. All-weather operations are represented by a summary of LOC sequences initiated by weather-related events. Crew-automation vulnerability is 
represented by LOC sequences that were initiated by system faults and crew errors. Future intervention strategies for preventing LOC events will need to be able to provide interventions for these sequences with an emphasis on takeoffs and landings under wake and wind shear conditions, terminal area maneuvering and landing under vehicle impairment conditions while penetrating external disturbances, and self-separation and abrupt maneuvering for collision avoidance under all-weather and vehicle impairment conditions.

\section{High-Density Related Sequences:}

\section{Accidents, 137 Fatalities:}
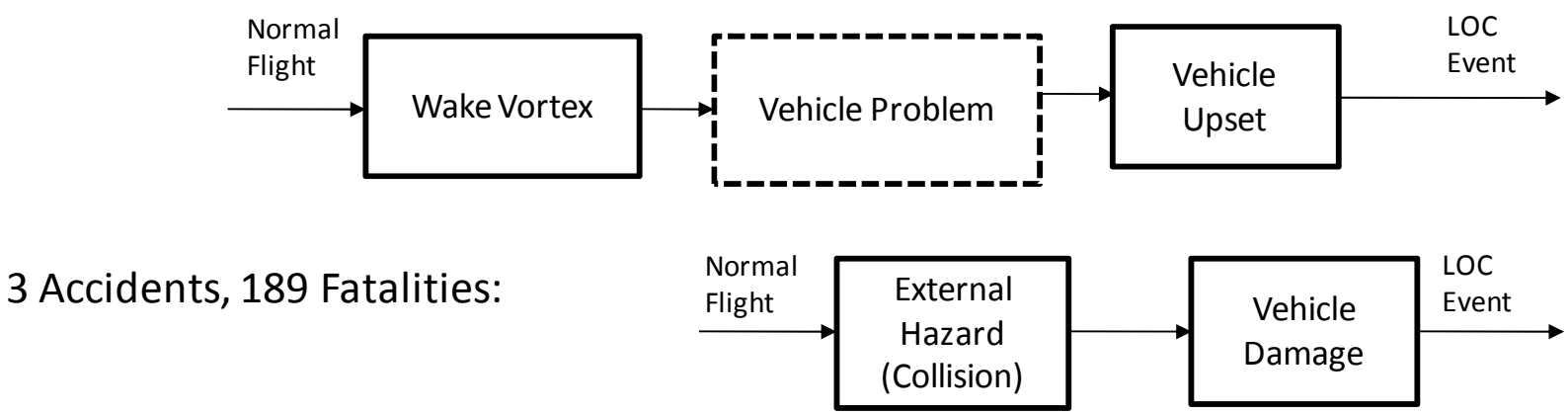

Figure 20a. Potential LOC Sequences Related to Future Risk (High-Density Related Sequences).

All-Weather Related Sequences:

24 Accidents, 851 Fatalities:

7 Accidents, 460 Fatalities:
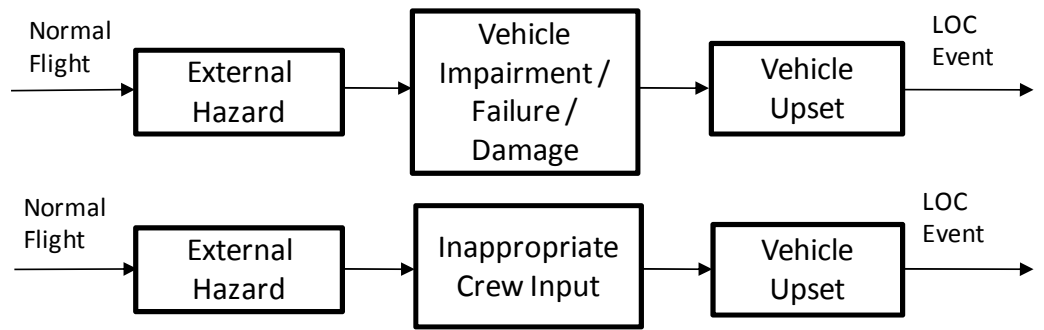

7 Accidents, 143 Fatalities:

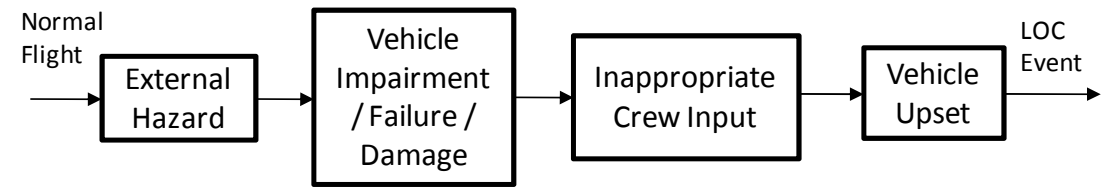

4 Accidents, 76 Fatalities:

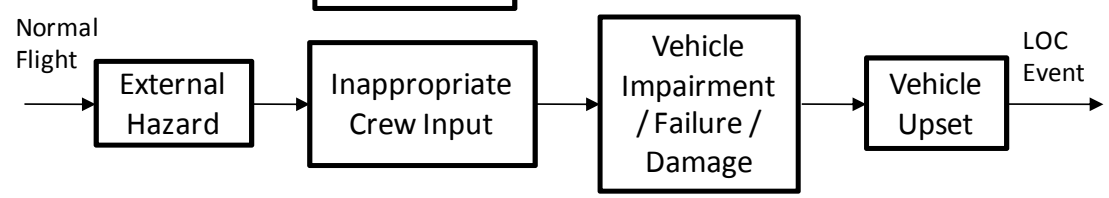

4 Accidents, 255 Fatalities:

1 Accidents, 125 Fatalities:

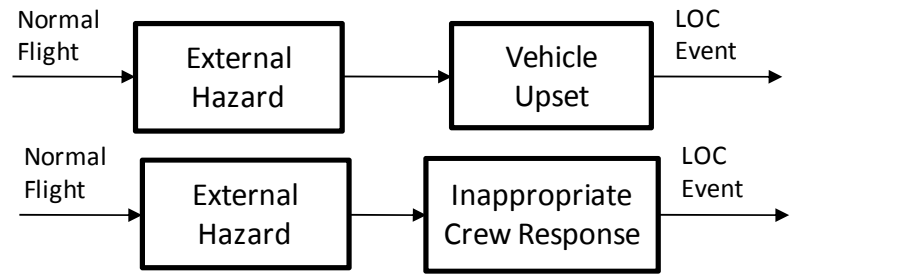

Figure 20b. Potential LOC Sequences Related to Future Risk (Weather Related Sequences). 


\section{Crew-Automation Related Sequences:}

7 Accidents, 741 Fatalities:

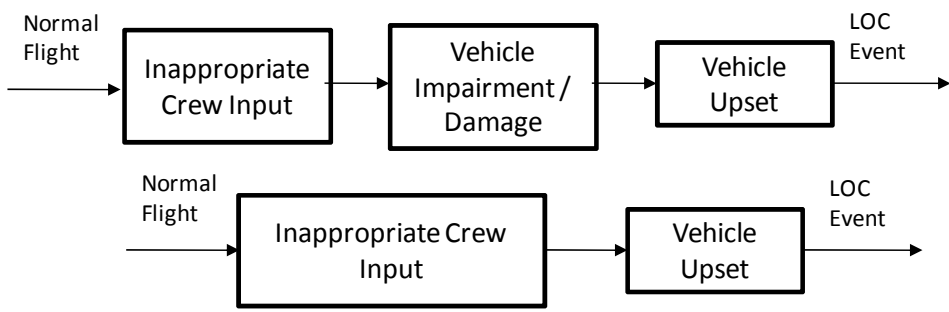

9 Accidents, 349 Fatalities:

6 Accidents, 304 Fatalities:

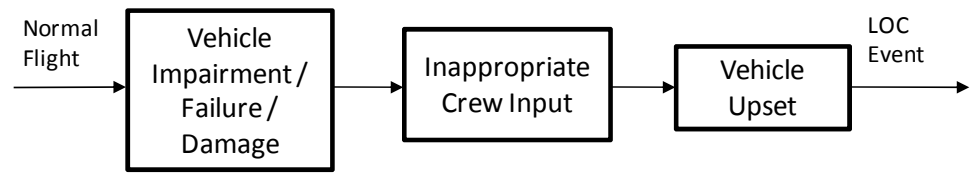

3 Accidents, 493 Fatalities:

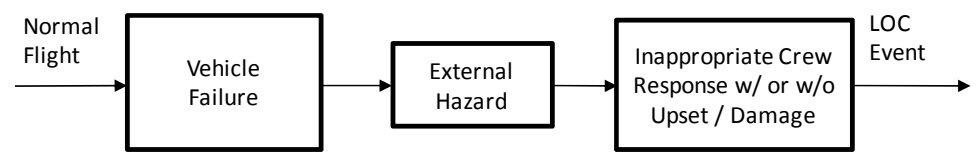

1 Accident, 5 Fatalities:

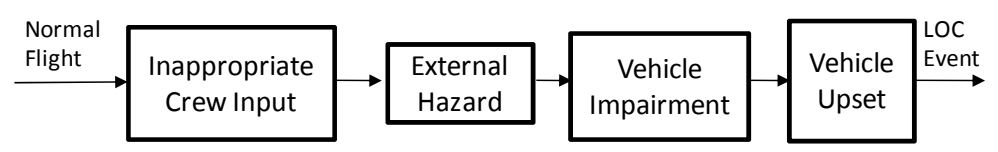

Figure 20c. Potential LOC Sequences Related to Future Risk (Crew-Automation Related Sequences).

New LOC precursors associated with failure modes of future vehicle and airspace systems must also be identified and considered (particularly during V\&V of these systems), and their potential ramifications considered (particularly under off-nominal operating conditions). New types of crew-induced LOC precursors must also be considered.

\section{Conclusion}

Aircraft LOC accidents cause a significant percentage of aviation fatalities across all aircraft classes and operations, and result from a large number of causal and contributing factors that occur individually or (more often) in combination. A detailed analysis of causal and contributing factors associated with aircraft LOC accidents (predominantly for Part 121 operations) has been performed and documented in this paper. The LOC accidents considered in this paper included accidents that involved vehicle upsets, as well as those involving failures, impairment, or damage to the flight control capability of the aircraft (including control surfaces, flight control system or components, and the engines) or to the vehicle airframe (when the damage was sufficient to alter vehicle dynamics and control characteristics) whether or not they led to an upset condition (or there was evidence of upset cited in the report). The data set used in the analysis consisted of 126 LOC accidents that resulted in 6087 fatalities during the 30-year period 1979 - 2009. The analysis included the identification of worst case combinations of causal and contributing factors using scatter plots generated from the accident data, and a detailed compilation of LOC sequences based on temporal ordering of causal and contributing factors. A list of the top 10 LOC summarized sequences was developed, which represents $86.5 \%$ of the accidents and $89.1 \%$ of the fatalities considered in this paper. A set of 7 generalized LOC sequences was also defined, which are representative of $88.9 \%$ of the accidents and $90.8 \%$ of the fatalities considered in this study. The data set was analyzed for trends potentially attributable to the introduction of new technologies in the last 15 years. This analysis showed little effect. The data was also analyzed for differences between nonfatal and fatal accidents. This analysis also did not yield significant results. Finally, future risks with the potential to increase LOC accidents were considered. Research in the development of holistic intervention strategies that can prevent LOC accidents under current and future airspace operations is recommended. 


\section{Appendix}

\begin{tabular}{|c|c|c|c|c|c|c|c|}
\hline Date & $\begin{array}{l}\text { Aircraft / } \\
\text { Airline }\end{array}$ & Location & $\begin{array}{c}\text { Fatalities } \\
\text { (Total } \\
\text { Onboard) }\end{array}$ & Phase of Flight & $\begin{array}{l}\text { Accident } \\
\text { Summary }\end{array}$ & $\begin{array}{c}\text { Probable Primary } \\
\text { Cause }\end{array}$ & $\begin{array}{l}\text { Accident } \\
\text { No. }\end{array}$ \\
\hline $9 / 24 / 2009$ & \begin{tabular}{|c|} 
British \\
Aerospace \\
4121 \\
Jetstream 41, \\
ZS-NRM / \\
SA Airlink \\
\end{tabular} & \begin{tabular}{|} 
Merebank, Near \\
Durban \\
International \\
Airport \\
South Africa
\end{tabular} & 0 & Takeoff & $\begin{array}{c}\text { System / Component } \\
\text { Failure - Engine }\end{array}$ & Engine Failure & 1 \\
\hline 8/3/2009 & $\begin{array}{l}\text { B707, EP- } \\
\text { SHK / } \\
\text { Saha Air } \\
\text { (Flt. 124) }\end{array}$ & $\begin{array}{l}\text { Ahwaz Airport, } \\
\text { Iran }\end{array}$ & 0 & Cruise & $\begin{array}{l}\text { Uncontained Engine } \\
\text { Failure Resulting in } \\
\text { Unknown Level of } \\
\text { Vehicle Damage }\end{array}$ & $\begin{array}{l}\text { System / Component } \\
\text { Failure - Engine }\end{array}$ & 2 \\
\hline 7/13/2009 & $\begin{array}{c}\text { B737, } \\
\text { N387SW / } \\
\text { Southwest } \\
\text { Airlines } \\
\text { (Flt. 2294) }\end{array}$ & $\begin{array}{l}\text { Near Charleston, } \\
\text { WV, USA }\end{array}$ & 0 & Cruise & \begin{tabular}{|c|} 
Vehicle suffered \\
rapid decompression \\
resulting from a hole \\
in the fuselage \\
measuring 17"x8"
\end{tabular} & $\begin{array}{c}\text { Damage to fuselage from } \\
\text { unknown source }\end{array}$ & 3 \\
\hline $6 / 1 / 2009$ & $\begin{array}{l}\text { A330, F- } \\
\text { GZCP / } \\
\text { Air France }\end{array}$ & $\begin{array}{c}\sim 160 \mathrm{~km} \text { NNW } \\
\text { off Sao Pedro and } \\
\text { Sao Paulo } \\
\text { Archipelago in } \\
\text { the Atlantic } \\
\text { Ocean }\end{array}$ & 228 (228) & Cruise & $\begin{array}{c}\text { Instrument failure of } \\
\text { the Air Data Inertial } \\
\text { Reference Unit } \\
\text { (ADIRU), possibly } \\
\text { coupled with severe } \\
\text { turbulence }\end{array}$ & $\begin{array}{l}\text { System/Component } \\
\text { Failure - Airspeed } \\
\text { Instrumentation }\end{array}$ & 4 \\
\hline 2/25/2009 & $\begin{array}{l}\text { B737, TC- } \\
\text { JGE / } \\
\text { Turk Hava } \\
\text { Yollari } \\
\text { (Flt. 1951) }\end{array}$ & $\begin{array}{l}1.5 \mathrm{~km} \mathrm{~N} \text { of } \\
\text { Amsterdam- } \\
\text { Schiphol } \\
\text { International } \\
\text { Airport } \\
\text { Netherlands }\end{array}$ & 9 (135) & Approach/Landing & $\begin{array}{c}\text { Possible fault with } \\
\text { radio altimeter, } \\
\text { Possible fault in } \\
\text { autothrottle system, } \\
\text { Possible mode } \\
\text { confusion by crew, } \\
\text { Aircraft Stall } \\
\end{array}$ & $\begin{array}{c}\text { System/Component } \\
\text { Error - Flight Control } \\
\text { System (Flight systems } \\
\text { drove aircraft into a stall) }\end{array}$ & 5 \\
\hline $2 / 12 / 2009$ & \begin{tabular}{|c|} 
de Havilland \\
Canada \\
DHC-8, \\
N200WQ / \\
Colgan Air \\
(Flt. 3407)
\end{tabular} & $\begin{array}{c}10 \mathrm{~km} \text { NE of } \\
\text { Buffalo Niagara } \\
\text { International } \\
\text { Airport, NY }\end{array}$ & $\begin{array}{l}49(49) \\
+1 \text { on } \\
\text { Ground }\end{array}$ & Approach & $\begin{array}{c}\text { Vehicle stall possibly } \\
\text { due to vehicle } \\
\text { impairment from } \\
\text { icing combined with } \\
\text { inappropriate crew } \\
\text { input for recovery }\end{array}$ & $\begin{array}{c}\text { Inappropriate Crew } \\
\text { Response During Stall } \\
\text { Recovery }\end{array}$ & 6 \\
\hline 2/7/2009 & \begin{tabular}{|c|} 
Embraer 110, \\
PT-SEA / \\
Manaus \\
Aerotaxi
\end{tabular} & $\begin{array}{l}\text { Off Santo } \\
\text { Antonio, AM } \\
\text { Brazil }\end{array}$ & $24(28)$ & Cruise & $\begin{array}{l}\text { Loss of control due } \\
\text { to weather, engine } \\
\text { failure, and possible } \\
\text { overloaded condition }\end{array}$ & \begin{tabular}{|c|} 
System and Component \\
Failure - Engine
\end{tabular} & 7 \\
\hline 1/15/2009 & $\begin{array}{c}\text { A320, } \\
\text { N106US / } \\
\text { US Airways } \\
\text { (Flt. 1549) }\end{array}$ & $\begin{array}{c}\text { Off Weehawkin, } \\
\text { NJ [Hudson } \\
\text { River, NY] USA }\end{array}$ & 0 & $\begin{array}{l}\text { Takeoff - Initial } \\
\text { Climb }\end{array}$ & $\begin{array}{l}\text { Damage to both } \\
\text { engines due to } \\
\text { impact with flock of } \\
\text { geese }\end{array}$ & $\begin{array}{l}\text { Vehicle Damage - } \\
\text { Engines }\end{array}$ & 8 \\
\hline
\end{tabular}




\begin{tabular}{|c|c|c|c|c|c|c|c|}
\hline $1 / 4 / 2009$ & $\begin{array}{c}\text { Cessna 550, } \\
\text { N815MA / } \\
\text { Caribair, } \\
\text { S.A. }\end{array}$ & $\begin{array}{c}\text { Wilmington-New } \\
\text { Hanover County } \\
\text { International } \\
\text { Airport, NC, } \\
\text { USA }\end{array}$ & 0 & Approach/Landing & $\begin{array}{c}\text { Poor Visibility } \\
\text { forced } 3 \text { Missed } \\
\text { Approaches, Loss of } \\
\text { both engines due to } \\
\text { low fuel on fourth } \\
\text { approach }\end{array}$ & $\begin{array}{c}\text { Inappropriate Crew } \\
\text { Action Resulting in } \\
\text { Vehicle Impairment - } \\
\text { Engines }\end{array}$ & 9 \\
\hline $11 / 27 / 2008$ & \begin{tabular}{|c|} 
A320, D- \\
AXLA / \\
XL Airways \\
Germany \\
(Leased from \\
Air New \\
Zealand)
\end{tabular} & $\begin{array}{c}5 \mathrm{~km} \text { E off } \\
\text { Canet-Plage, } \\
\text { France }\end{array}$ & $7(7)$ & \begin{tabular}{|c|} 
Approach / Go- \\
Around (following \\
maintenance \\
during a low- \\
speed check to \\
activate the alpha \\
floor protection \\
system)
\end{tabular} & \begin{tabular}{|} 
Aircraft was flown \\
into stall on \\
approach by crew \\
and/or flight control \\
system during \\
checkout flight - \\
recovery was \\
impaired by the \\
vehicle being \\
configured \\
inappropriately for \\
go-around
\end{tabular} & Stall & 10 \\
\hline $10 / 7 / 2008$ & \begin{tabular}{|} 
A330, VH- \\
QPA / \\
Qantas \\
(Flt. QF72)
\end{tabular} & $\begin{array}{c}154 \mathrm{~km} \mathrm{~W} \text { of } \\
\text { Learmonth, WA, } \\
\text { Australia }\end{array}$ & 0 & Cruise & $\begin{array}{l}\text { Failure of the air data } \\
\text { IRU resulting in } \\
\text { uncommanded pitch } \\
\text { downs during cruise }\end{array}$ & $\begin{array}{l}\text { System and Component } \\
\text { Failure - ADIRU }\end{array}$ & 11 \\
\hline 9/14/2008 & $\begin{array}{l}\text { B737, VP- } \\
\text { BKO / } \\
\text { Aeroflot- } \\
\text { Nord } \\
\text { (Flt. 821) }\end{array}$ & $\begin{array}{l}11.5 \text { km NE of } \\
\text { Perm Airport, } \\
\text { Russia }\end{array}$ & $88(88)$ & Approach & $\begin{array}{l}\text { Uncontrolled descent } \\
\text { resulting from spatial } \\
\text { disorientation of the } \\
\text { crew and possible } \\
\text { atmospheric } \\
\text { disturbances }\end{array}$ & $\begin{array}{c}\text { Crew Spatial } \\
\text { Disorientation }\end{array}$ & 12 \\
\hline $9 / 1 / 2008$ & \begin{tabular}{|c|} 
Convair 580, \\
N587X / \\
Air Tahoma
\end{tabular} & $\begin{array}{l}1.6 \mathrm{~km} \text { SW of } \\
\text { Columbus- } \\
\text { Rickenbacker } \\
\text { International } \\
\text { Airport, OH, } \\
\text { USA }\end{array}$ & $3(3)$ & $\begin{array}{l}\text { Emergency } \\
\text { Landing }\end{array}$ & $\begin{array}{l}\text { Loss-of-Control } \\
\text { resulting from } \\
\text { reverse rigging of } \\
\text { elevator trim cables }\end{array}$ & Elevator System Failure & 13 \\
\hline $8 / 20 / 2008$ & \begin{tabular}{|c|} 
MD-82, EC- \\
HFP / \\
Spanair \\
(Flt. 5022)
\end{tabular} & $\begin{array}{l}\text { Madrid-Barajas } \\
\text { Airport, } \\
\text { Spain }\end{array}$ & $154(172)$ & Takeoff & \begin{tabular}{|c|} 
Stall During Takeoff \\
Resulting from \\
Inappropriate \\
Vehicle \\
Configuration
\end{tabular} & $\begin{array}{c}\text { Stall - Inappropriate } \\
\text { Vehicle Configuration }\end{array}$ & 14 \\
\hline $7 / 7 / 2008$ & $\begin{array}{c}\text { B747, } \\
\text { N714CK / } \\
\text { Centurion } \\
\text { Air Cargo }\end{array}$ & $\begin{array}{c}8 \mathrm{~km} \mathrm{~N} \text { of } \\
\text { Bogota-Eldorado } \\
\text { Airport, } \\
\text { Colombia }\end{array}$ & $\begin{array}{c}0 \\
+3 \text { on } \\
\text { ground }\end{array}$ & $\begin{array}{l}\text { Takeoff - Initial } \\
\text { Climb }\end{array}$ & $\begin{array}{l}\text { Engine Fire during } \\
\text { Initial Climb }\end{array}$ & Engine Failure & 15 \\
\hline $6 / 10 / 2008$ & $\begin{array}{l}\text { A310, ST- } \\
\text { ATN / } \\
\text { Sudan } \\
\text { Airways } \\
\text { (Flt. 109) }\end{array}$ & $\begin{array}{l}\text { Khartoum-Civil } \\
\text { Airport, } \\
\text { Sudan }\end{array}$ & $30(214)$ & Landing & $\begin{array}{c}\text { Aircraft crashed on } \\
\text { landing, possibly due } \\
\text { to wind shear }\end{array}$ & $\begin{array}{l}\text { Atmospheric } \\
\text { Disturbance }\end{array}$ & 16 \\
\hline
\end{tabular}

23

American Institute of Aeronautics and Astronautics 


\begin{tabular}{|c|c|c|c|c|c|c|c|}
\hline $5 / 2 / 2008$ & $\begin{array}{l}\text { Beechcraft } \\
\text { 1900, 5Y- } \\
\text { FLX / } \\
\text { Southern } \\
\text { Sudan Air } \\
\text { Connection }\end{array}$ & $\begin{array}{l}\text { 45km NW of } \\
\text { Rumbek, } \\
\text { Sudan }\end{array}$ & $21(21)$ & Cruise & $\begin{array}{c}\text { Failure of both } \\
\text { engines during cruise }\end{array}$ & Engine Failure & 17 \\
\hline $2 / 7 / 2008$ & \begin{tabular}{|c|} 
Britten- \\
Norman BN- \\
2A, HI- \\
653CA / \\
Caribair, \\
S.A. \\
\end{tabular} & $\begin{array}{l}\text { El Seibo, } \\
\text { Dominican } \\
\text { Republic }\end{array}$ & 0 & Enroute & $\begin{array}{l}\text { Crash-landed after } \\
\text { Engine Failure }\end{array}$ & Engine Failure & 18 \\
\hline $1 / 17 / 2008$ & \begin{tabular}{|c|} 
B777, G- \\
YMMM / \\
British \\
Airways
\end{tabular} & \begin{tabular}{|c|} 
London- \\
Heathrow \\
Airport, \\
United Kingdom
\end{tabular} & 0 & Landing & $\begin{array}{c}\text { Engines failed to } \\
\text { respond to increased } \\
\text { thrust command } \\
\text { from autothrottle and } \\
\text { from flight crew } \\
\text { advancing the } \\
\text { throttle levers, } \\
\text { Aircraft entered an } \\
\text { uncontrolled descent }\end{array}$ & $\begin{array}{l}\text { System and Component } \\
\text { Failure - Engines } \\
\\
\end{array}$ & 19 \\
\hline $1 / 4 / 2008$ & $\begin{array}{l}\text { Let 410, } \\
\text { YV2081 / } \\
\text { Transaven }\end{array}$ & $\begin{array}{c}20 \mathrm{~km} \mathrm{~S} \mathrm{of} \mathrm{Los} \\
\text { Roques Airport, } \\
\text { Venezuela }\end{array}$ & $14(14)$ & Descent & \begin{tabular}{|c|}
$\begin{array}{c}\text { Failure of both } \\
\text { engines }\end{array}$ \\
\end{tabular} & $\begin{array}{c}\text { System and Component } \\
\text { Failure - Engines }\end{array}$ & 20 \\
\hline $5 / 5 / 2007$ & $\begin{array}{c}\text { B737-800, } \\
\text { 5Y-KYA / } \\
\text { Kenya } \\
\text { Airways }\end{array}$ & $\begin{array}{c}5.5 \mathrm{~km} \mathrm{SE} \text { of } \\
\text { Douala Airport } \\
\text { Cameroon }\end{array}$ & 114 (114) & $\begin{array}{l}\text { Takeoff - Initial } \\
\text { Climb }\end{array}$ & $\begin{array}{c}\text { Vehicle Upset } \\
\text { resulting from } \\
\text { possible wind shear } \\
\text { and/or inappropriate } \\
\text { crew response }\end{array}$ & $\begin{array}{c}\text { Atmospheric } \\
\text { Disturbances, } \\
\text { Inappropriate Crew } \\
\text { Response }\end{array}$ & 21 \\
\hline $1 / 1 / 2007$ & $\begin{array}{c}\text { B737-4Q8 } \\
\text { PK-KKW / } \\
\text { AdamAir }\end{array}$ & $\frac{85 \mathrm{~km}(53.1 \mathrm{mls})}{\underline{\text { W off }}} \underset{\underline{\text { Pambauang, }}}{\underline{\text { Indonesia }}}$ & $102(102)$ & Cruise & \begin{tabular}{|c|} 
Crew distracted with \\
trouble-shooting the \\
IRS, loss of \\
situational awareness \\
\& spatial \\
disorientation during \\
upset
\end{tabular} & \begin{tabular}{|c|} 
Loss of Situational \\
Awareness During \\
Failure, Leading to Upset \\
\end{tabular} & 22 \\
\hline 10/29/2006 & \begin{tabular}{|c} 
B737-2B7 \\
5N-BFK / \\
ADC \\
Airlines
\end{tabular} & $\begin{array}{l}\text { Near Abuja Int. } \\
\text { Airport (ABV) } \\
\text { Nigeria }\end{array}$ & $\begin{array}{l}96(105) \\
+1 \text { on } \\
\text { Ground }\end{array}$ & Takeoff & $\begin{array}{c}\text { Stall, possibly } \\
\text { resulting from wind } \\
\text { shear and gusts }\end{array}$ & Stall & 23 \\
\hline 9/29/2006 & $\begin{array}{c}\text { B737-8EH } \\
\text { PR-GTD / } \\
\text { GOL } \\
\text { Transportes } \\
\text { Aereos }\end{array}$ & \begin{tabular}{|c}
30 km from \\
Peixoto Azevedo, \\
MT \\
Brazil
\end{tabular} & 154 (154) & Cruise & $\begin{array}{c}\text { Mid-Air Collision } \\
\text { Resulting in Vehicle } \\
\text { Damage }\end{array}$ & Mid-Air Collision & 24 \\
\hline $7 / 10 / 2006$ & $\begin{array}{c}\text { Fokker F-27 } \\
\text { Friendship } \\
200 \text { AP-BAL } \\
/ \\
\text { Pakistan } \\
\text { International } \\
\text { Airlines }\end{array}$ & $\begin{array}{c}\text { Near Multan } \\
\text { Airport (MUX) } \\
\text { Pakistan }\end{array}$ & $45(45)$ & $\begin{array}{c}\text { Takeoff - Struck } \\
\text { Electrical Power } \\
\text { Lines }\end{array}$ & $\begin{array}{c}\text { Engine failure on } \\
\text { takeoff leading to } \\
\text { collision with } \\
\text { external hazard } \\
\text { (power lines) }\end{array}$ & Engine Failure & 25 \\
\hline
\end{tabular}

24

American Institute of Aeronautics and Astronautics 


\begin{tabular}{|c|c|c|c|c|c|c|c|}
\hline 7/9/2006 & \begin{tabular}{|c|} 
Airbus \\
A.310-324 F- \\
OGYP / \\
S7 Airlines
\end{tabular} & $\begin{array}{c}\text { Irkutsk Airport } \\
\text { (IKT) } \\
\text { Russia }\end{array}$ & 125 (203) & $\begin{array}{l}\text { Landing - Over- } \\
\text { ran Runway }\end{array}$ & $\begin{array}{c}\text { Rain/Thunderstorms, } \\
\text { During landing pilot } \\
\text { inadvertently } \\
\text { touched \#1 power } \\
\text { lever increasing } \\
\text { thrust - No. } 1 \text { engine } \\
\text { thrust reverser de- } \\
\text { activated \& set to } \\
\text { idle, No.2 thrust } \\
\text { reverser deployed }\end{array}$ & $\begin{array}{l}\text { Inappropriate crew } \\
\text { inputs }\end{array}$ & 26 \\
\hline $5 / 3 / 2006$ & $\begin{array}{c}\text { Airbus } \\
\text { A.320-211 } \\
\text { EK-32009 / } \\
\text { Armavia } \\
\text { (Flt. 967) }\end{array}$ & $\begin{array}{c}6 \text { km SW Off } \\
\text { Adler/Sochi } \\
\text { Airport (AER) } \\
\text { Russia }\end{array}$ & $113(113)$ & $\begin{array}{l}\text { Approach } \\
\text { (Aborted - } \\
\text { Climbing Turn } \\
\text { Maneuver) }\end{array}$ & \begin{tabular}{|c|} 
Inappropriate crew \\
inputs (excessive \\
nose down pitch \\
commands) resulting \\
from possible wind \\
shear leading to \\
uncontrolled descent \\
\end{tabular} & $\begin{array}{l}\text { Inappropriate crew } \\
\text { inputs }\end{array}$ & 27 \\
\hline $1 / 2 / 2006$ & $\begin{array}{l}\text { Saab-340 } \\
\text { N-380AE / } \\
\text { American } \\
\text { Eagle }\end{array}$ & $\begin{array}{c}\text { Over } \\
\text { Santa Maria, CA } \\
\text { USA }\end{array}$ & 0 & Climb & $\begin{array}{c}\text { Vehicle upset } \\
\text { resulting from icing } \\
\text { conditions }\end{array}$ & Icing & 28 \\
\hline $10 / 22 / 2005$ & $\begin{array}{l}\text { B737, 5N- } \\
\text { BFN / } \\
\text { Bellview } \\
\text { Airlines }\end{array}$ & $\begin{array}{l}\text { Near Lisa } \\
\text { Nigeria }\end{array}$ & 117 (117) & Takeoff & $\begin{array}{c}\text { Abnormal flight } \\
\text { trajectory on takeoff }\end{array}$ & Undetermined & 29 \\
\hline $9 / 5 / 2005$ & $\begin{array}{l}\text { B737-230, } \\
\text { PK-RIM / } \\
\text { Mandala } \\
\text { Airlines }\end{array}$ & $\begin{array}{l}\text { Medan-Polonia } \\
\text { Airport } \\
\text { Indonesia }\end{array}$ & $\begin{array}{l}100(117) \\
+49 \text { on } \\
\text { Ground }\end{array}$ & $\begin{array}{l}\text { Takeoff - Initial } \\
\text { Climb }\end{array}$ & $\begin{array}{c}\text { Airplane failed to } \\
\text { become airborne due } \\
\text { to inappropriate } \\
\text { vehicle configuration } \\
\text { - flaps and slats were } \\
\text { not deployed }\end{array}$ & $\begin{array}{l}\text { Inappropriate vehicle } \\
\text { configuration resulting } \\
\text { from crew error }\end{array}$ & 30 \\
\hline $9 / 5 / 2005$ & $\begin{array}{l}\text { B737, PR- } \\
\text { BRY / }\end{array}$ & & 0 & Cruise & $\begin{array}{c}\text { Vehicle driven into } \\
\text { an upset condition by } \\
\text { the autopilot }\end{array}$ & Autopilot Failure & 31 \\
\hline $8 / 16 / 2005$ & \begin{tabular}{|c|} 
MD-80, HK- \\
$4374 X$ / \\
West \\
Caribbean \\
Airways \\
(Flt 708)
\end{tabular} & $\begin{array}{c}\text { Near Machiques } \\
\text { Venezuela }\end{array}$ & $160(160)$ & Cruise & \begin{tabular}{|c|} 
Stall resulting from \\
possible engine icing \\
condition or failure
\end{tabular} & $\begin{array}{c}\text { Stall, Engine } \\
\text { Failure/Impairment }\end{array}$ & 32 \\
\hline $8 / 1 / 2005$ & $\begin{array}{c}\text { B777, 9M- } \\
\text { MRG / } \\
\text { Malaysia } \\
\text { Airlines } \\
\text { (Flt 124) }\end{array}$ & $\begin{array}{c}240 \text { km NW of } \\
\text { Perth, WA } \\
\text { Australia }\end{array}$ & 0 & Climb & \begin{tabular}{|c|} 
Fault in flight control \\
instrumentation \\
system and software \\
leading to vehicle \\
upset (Software error \\
allowed faulty sensor \\
to be used by \\
primary flight \\
control system)
\end{tabular} & $\begin{array}{c}\text { Flight control system } \\
\text { fault }\end{array}$ & 33 \\
\hline
\end{tabular}




\begin{tabular}{|c|c|c|c|c|c|c|c|}
\hline $5 / 27 / 2005$ & $\begin{array}{l}\text { DHC-8, C- } \\
\text { GZKH / } \\
\text { Provincial } \\
\text { Airlines } \\
\text { Limited }\end{array}$ & $\begin{array}{c}\text { Near } \\
\text { Newfoundland }\end{array}$ & 0 & $\begin{array}{l}\text { Takeoff - Initial } \\
\text { Climb }\end{array}$ & $\begin{array}{c}\text { Vehicle Stall during } \\
\text { initial climb Induced } \\
\text { by Icing and coupled } \\
\text { with inappropriate } \\
\text { crew response (Crew } \\
\text { Interpreted Upset as } \\
\text { Severe Turbulence, } \\
\text { which Delayed } \\
\text { Effective Stall } \\
\text { Recovery) }\end{array}$ & Stall, Icing & 34 \\
\hline $11 / 28 / 2004$ & \begin{tabular}{|c|} 
Canadair CL- \\
600, N873G / \\
Global \\
Aviation \\
(Flt 73)
\end{tabular} & $\begin{array}{c}\text { Montrose County } \\
\text { Airport, CO } \\
\text { USA }\end{array}$ & $3(6)$ & Takeoff & $\begin{array}{c}\text { Stall Induced by } \\
\text { Icing during takeoff }\end{array}$ & Stall, Icing & 35 \\
\hline $11 / 21 / 2004$ & \begin{tabular}{|c|} 
Canadair CL- \\
600, B-3072 \\
$/$ \\
China \\
Yunnan \\
Airlines \\
(Flt 5210)
\end{tabular} & $\begin{array}{l}\text { Near Baotou } \\
\text { Airport } \\
\text { China }\end{array}$ & $\begin{array}{l}53(53) \\
+2 \text { on } \\
\text { Ground }\end{array}$ & $\begin{array}{l}\text { Takeoff - Initial } \\
\text { Climb }\end{array}$ & $\begin{array}{c}\text { Stall induced by } \\
\text { Icing during initial } \\
\text { climb }\end{array}$ & Stall, Icing & 36 \\
\hline $10 / 14 / 2004$ & \begin{tabular}{|c|} 
Canadair CL- \\
600, N8396A \\
$/$ \\
Pinnacle \\
Airlines / \\
Northwest \\
Airlink \\
(Flt 3701)
\end{tabular} & $\begin{array}{l}\text { Jefferson City, } \\
\text { MO USA }\end{array}$ & $2(2)$ & Approach & $\begin{array}{l}\text { Stall Induced by } \\
\text { Engine Failure } \\
\text { (Double Engine } \\
\text { Flame-Out) }\end{array}$ & Stall, Engine Failure & 37 \\
\hline $6 / 18 / 2004$ & $\begin{array}{c}\text { Saab-SF340 } \\
\text { VH-KEQ / }\end{array}$ & $\begin{array}{c}83 \text { km SW } \\
\text { Albury } \\
\text { Australia }\end{array}$ & 0 & Descent & $\begin{array}{c}\text { Contaminated Airfoil } \\
\text { due to Icing }\end{array}$ & Stall due to Icing & 38 \\
\hline $1 / 3 / 2004$ & $\begin{array}{l}\text { B737-300 } \\
\text { SU-ZCF / } \\
\text { Flash } \\
\text { Airlines } \\
\text { (Flt 604) }\end{array}$ & $\begin{array}{c}\text { Red Sea, Near } \\
\text { Sharm El-Sheikh, } \\
\text { Eqypt }\end{array}$ & $148(148)$ & Takeoff & \begin{tabular}{|c|} 
Loss of Control \\
resulting from \\
inappropriate control \\
actions by the crew \\
due to spatial \\
disorientation \\
\end{tabular} & $\begin{array}{l}\text { Spatial Disorientation, } \\
\text { Spiral Dive }\end{array}$ & 39 \\
\hline $10 / 3 / 2003$ & \begin{tabular}{|c|} 
Convair CV- \\
580, ZK- \\
KFU / \\
Air Freight \\
NZ \\
(Flt 642)
\end{tabular} & $\begin{array}{l}10 \text { km N off } \\
\text { Paraparaumu, } \\
\text { New Zealand }\end{array}$ & $2(2)$ & Initial Descent & $\begin{array}{l}\text { Icing-induced stall } \\
\text { and departure } \\
\text { resulting in severe } \\
\text { vehicle damage }\end{array}$ & Stall, Icing and Damage & 40 \\
\hline $7 / 8 / 2003$ & $\begin{array}{l}\text { B737, ST- } \\
\text { AFK / } \\
\text { Sudan } \\
\text { Airways } \\
\text { (Flt 139) }\end{array}$ & $\begin{array}{l}5 \mathrm{~km} \text { E of } \\
\text { Port Sudan } \\
\text { Sudan }\end{array}$ & $116(117)$ & Missed Approach & $\begin{array}{l}\text { Loss of control due } \\
\text { to engine failure }\end{array}$ & Engine Failure & 41 \\
\hline
\end{tabular}




\begin{tabular}{|c|c|c|c|c|c|c|c|}
\hline 4/23/2003 & $\begin{array}{l}\text { Beechcraft } \\
\text { 99, } \\
\text { C-FDYF / } \\
\text { Transwest } \\
\text { Air } \\
\text { (Flt 602) }\end{array}$ & $\begin{array}{c}11 \text { km from } \\
\text { Prince Albert, SK } \\
\text { Canada }\end{array}$ & 0 & Approach & \begin{tabular}{|c|} 
Vehicle upset \\
resulting from Flight \\
control system \\
failure (Horizontal \\
stabilizer failure / \\
detachment resulting \\
from improper \\
maintenance) \\
\end{tabular} & $\begin{array}{l}\text { Flight control system } \\
\text { failure }\end{array}$ & 42 \\
\hline $1 / 8 / 2003$ & $\begin{array}{c}\text { Beechcraft } \\
\text { 1900, } \\
\text { N233YV / } \\
\text { US Airways } \\
\text { Express } \\
\text { (Flt 5481) }\end{array}$ & $\begin{array}{l}\text { Charlotte- } \\
\text { Douglas } \\
\text { International } \\
\text { Airport, NC } \\
\text { USA }\end{array}$ & $21(21)$ & $\begin{array}{l}\text { Takeoff - Initial } \\
\text { Climb }\end{array}$ & \begin{tabular}{|c|} 
Loss of pitch control \\
due to flight control \\
system fault (Fault of \\
the elevator system \\
due to an improper \\
maintenance action)
\end{tabular} & $\begin{array}{c}\text { Flight control system } \\
\text { fault }\end{array}$ & 43 \\
\hline $12 / 21 / 2002$ & \begin{tabular}{|c|} 
Aerospatiale \\
ATR-72, B- \\
22708 / \\
Transasia \\
Airways (Flt \\
791 )
\end{tabular} & $\begin{array}{l}\text { 11.3 km NW off } \\
\text { Pachao Tao, } \\
\text { Penghu Islands } \\
\text { (Taiwan) }\end{array}$ & $2(2)$ & $\begin{array}{l}\text { Cruise - During } \\
\text { Descent }\end{array}$ & \begin{tabular}{|c|} 
Stall during descent \\
(undetermined cause)
\end{tabular} & Stall & 44 \\
\hline $12 / 7 / 2002$ & $\begin{array}{l}\text { A-320, C- } \\
\text { GJVX / } \\
\text { Air Canada } \\
\text { (Flt 457) }\end{array}$ & \begin{tabular}{|c|} 
Lester B. Pearson \\
International \\
Airport, Toronto, \\
Ontario, Canada
\end{tabular} & 0 & Landing & $\begin{array}{l}\text { Vehicle Upset (roll } \\
\text { oscillation on } \\
\text { landing) due to } \\
\text { possible } \\
\text { contaminated airfoil } \\
\text { from icing or PIO }\end{array}$ & $\begin{array}{c}\text { Upset/PIO due to } \\
\text { Contaminated Airfoil }\end{array}$ & 45 \\
\hline $12 / 7 / 2002$ & $\begin{array}{l}\text { A-320, C- } \\
\text { GIUF / } \\
\text { Air Canada } \\
\text { (Flt 1130) }\end{array}$ & \begin{tabular}{|} 
Lester B. Pearson \\
International \\
Airport, Toronto, \\
Ontario, Canada
\end{tabular} & 0 & $\begin{array}{l}\text { Landing - During } \\
\text { Go Around }\end{array}$ & $\begin{array}{l}\text { Vehicle Upset (roll } \\
\text { oscillation on } \\
\text { landing) due to } \\
\text { possible } \\
\text { contaminated airfoil } \\
\text { from icing or PIO }\end{array}$ & $\begin{array}{l}\text { Upset/PIO due to } \\
\text { Contaminated Airfoil }\end{array}$ & 46 \\
\hline $10 / 20 / 2002$ & $\begin{array}{l}\text { B757-200, } \\
\text { TF-FII / } \\
\text { Icelandair } \\
\text { (Flt 662) }\end{array}$ & $\begin{array}{l}\text { Near Baltimore- } \\
\text { Washington } \\
\text { International } \\
\text { Airport, MD } \\
\text { USA }\end{array}$ & 0 & $\begin{array}{l}\text { Cruise - During } \\
\text { Vehicle Climb }\end{array}$ & \begin{tabular}{|c|} 
Stall induced by \\
system anomalies \\
(Instrument problem \\
with flight director \\
and airspeed \\
indicator displays \\
and/or Air Data \\
Computer) and \\
possible loss of crew \\
situational awareness
\end{tabular} & $\begin{array}{l}\text { Stall, Instrumentation } \\
\text { Error }\end{array}$ & 47 \\
\hline $6 / 28 / 2002$ & \begin{tabular}{|c|} 
Saab SF-340, \\
VH-OLM / \\
Hazelton \\
Airlines \\
(Flt 185)
\end{tabular} & $\begin{array}{c}7 \text { km ESE of } \\
\text { Bathurst, NSW } \\
\text { Australia }\end{array}$ & 0 & Approach & $\begin{array}{c}\text { Vehicle upset/stall } \\
\text { induced by icing and } \\
\text { Failure by crew to } \\
\text { activate de-icing } \\
\text { system }\end{array}$ & $\begin{array}{l}\text { Icing coupled with crew } \\
\text { inaction }\end{array}$ & 48 \\
\hline $6 / 14 / 2002$ & $\begin{array}{l}\text { A-340, C- } \\
\text { GHLM / } \\
\text { Air Canada } \\
\text { (Flt. 875) }\end{array}$ & $\begin{array}{c}\text { Frankfurt } \\
\text { Germany ILS } \\
\text { Facility }\end{array}$ & 0 & Approach & $\begin{array}{c}\text { Possible Autopilot } \\
\text { Fault - Pitch to } 27 \\
\text { deg during } \\
\text { glideslope capture }\end{array}$ & System Fault & 49 \\
\hline
\end{tabular}




\begin{tabular}{|c|c|c|c|c|c|c|c|}
\hline $6 / 4 / 2002$ & $\begin{array}{l}\text { MD-80, } \\
\text { N823NK / } \\
\text { Spirit } \\
\text { Airlines } \\
\text { (Flt 970) }\end{array}$ & $\begin{array}{l}37 \mathrm{~km} \mathrm{~W} \text { of } \\
\text { Wichita, KS } \\
\text { USA }\end{array}$ & 0 & Cruise & \begin{tabular}{|} 
Autopilot-induced \\
stall resulting from \\
icing (Engine power \\
loss resulting from \\
false engine pressure \\
ratio indication \\
caused by icing of \\
engine inlet probes \\
while in Autopilot \\
Mode)
\end{tabular} & Stall & 50 \\
\hline $5 / 4 / 2002$ & $\begin{array}{c}\text { British } \\
\text { Aircraft } \\
\text { Corp. 111, } \\
\text { 5N-ESF / } \\
\text { Executive } \\
\text { Airline } \\
\text { Services } \\
\text { (Flt. 4226) }\end{array}$ & $\begin{array}{l}\text { Kano, } \\
\text { Nigeria }\end{array}$ & $\begin{array}{l}71(77) \\
+78 \text { on } \\
\text { Ground }\end{array}$ & $\begin{array}{c}\text { Shortly afer } \\
\text { Takeoff }\end{array}$ & $\begin{array}{l}\text { Stall, Possibly } \\
\text { Resulting from } \\
\text { Engine Failure }\end{array}$ & Stall & 51 \\
\hline $1 / 4 / 2002$ & \begin{tabular}{|c|} 
Canadair CL- \\
600, N90AG \\
$/$ \\
Epps Air \\
Service \\
(Executive \\
Flight)
\end{tabular} & \begin{tabular}{|} 
Birmingham \\
International \\
Airport, \\
United Kingdom \\
\end{tabular} & $5(5)$ & $\begin{array}{l}\text { Takeoff - Initial } \\
\text { Climb }\end{array}$ & $\begin{array}{c}\text { Stall due to } \\
\text { contaminated airfoil } \\
\text { coupled with } \\
\text { Possible impairment } \\
\text { of crew due to } \\
\text { combined effects of } \\
\text { non-prescription } \\
\text { drug, jet-lag, and } \\
\text { fatigue } \\
\end{array}$ & Stall & 52 \\
\hline $12 / 20 / 2001$ & $\begin{array}{l}\text { Cessna } 560 \\
\text { Citation V, } \\
\text { HB-VLV / } \\
\text { Eagle Air } \\
\text { (Flt. 220) }\end{array}$ & $\begin{array}{l}\text { Zurich-Kloten } \\
\text { Airport, } \\
\text { Switzerland }\end{array}$ & $2(2)$ & $\begin{array}{l}\text { Takeoff - Initial } \\
\text { Climb }\end{array}$ & $\begin{array}{c}\text { Spatial disorientation } \\
\text { resulting from poor } \\
\text { visibility }\end{array}$ & $\begin{array}{l}\text { Crew Spatial } \\
\text { Disorientation }\end{array}$ & 53 \\
\hline $11 / 12 / 2001$ & $\begin{array}{c}\text { A300-605R } \\
\text { N14053 / } \\
\text { American } \\
\text { Airlines } \\
\text { (Flt 587) }\end{array}$ & $\begin{array}{c}\text { Belle Harbor, NY } \\
\text { USA }\end{array}$ & $\begin{array}{l}260(260) \\
+5 \text { on } \\
\text { ground }\end{array}$ & Takeoff & \begin{tabular}{|c|} 
Pilot-Induced \\
Vehicle Damage \\
brought on by \\
excessive and \\
unnecessary reaction \\
to wake vortex \\
encounter \\
\end{tabular} & $\begin{array}{c}\text { Atmospheric } \\
\text { Disturbance and } \\
\text { Inappropriate Crew } \\
\text { Response }\end{array}$ & 54 \\
\hline $3 / 19 / 2001$ & $\begin{array}{c}\text { Embraer 120, } \\
\text { N266CA / } \\
\text { Comair/Delta } \\
\text { Connection } \\
\text { (Flt. 5054) }\end{array}$ & $\begin{array}{l}\text { Near West Palm } \\
\text { Beach, FL } \\
\text { USA }\end{array}$ & 0 & Descent & $\begin{array}{l}\text { Stall Resulting from } \\
\text { Icing Conditions }\end{array}$ & Stall, Icing & 55 \\
\hline $12 / 27 / 2000$ & \begin{tabular}{|c|} 
Embraer 120, \\
N721HS / \\
American \\
Eagle \\
(Flt. 230)
\end{tabular} & $\begin{array}{c}\text { O'Hare } \\
\text { International } \\
\text { Airport, } \\
\text { Chicago, IL } \\
\text { USA }\end{array}$ & 0 & $\begin{array}{l}\text { Takeoff - Initial } \\
\text { Climb }\end{array}$ & \begin{tabular}{|c|} 
Pitch Control System \\
Design Flaw \\
Resulting in \\
Excessive Nose-Up \\
Trim, Jammed \\
Stabilizer \\
\end{tabular} & $\begin{array}{c}\text { Flight Control System } \\
\text { Failure }\end{array}$ & 56 \\
\hline 10/26/2000 & $\begin{array}{l}\text { Bombardier } \\
\text { CL-600, } \\
\text { N958CA / } \\
\text { Comair }\end{array}$ & $\begin{array}{c}\text { Falmouth, KY } \\
\text { USA }\end{array}$ & 0 & Cruise & \begin{tabular}{c|} 
Vehicle Upset \\
Induced by Wake \\
Vortex Encounter
\end{tabular} & $\begin{array}{c}\text { Atmospheric } \\
\text { Disturbance, Wake }\end{array}$ & 57 \\
\hline
\end{tabular}




\begin{tabular}{|c|c|c|c|c|c|c|c|}
\hline $10 / 2 / 2000$ & $\begin{array}{l}\text { A340, TC- } \\
\text { JDN / } \\
\text { Turkish } \\
\text { Airlines }\end{array}$ & North Atlantic & 0 & Cruise & \begin{tabular}{|c|} 
Flight Control Mode \\
Change Triggered by \\
Severe Turbulence \\
Encounter, Coupled \\
with Crew Mode \\
Confusion
\end{tabular} & $\begin{array}{l}\text { Atmospheric } \\
\text { Disturbance, } \\
\text { Turbulence }\end{array}$ & 58 \\
\hline $8 / 23 / 2000$ & \begin{tabular}{|c|} 
A320, \\
EK / $40-$ \\
Air \\
(Flt. 072)
\end{tabular} & $\begin{array}{l}2 \text { km N off } \\
\text { Nahrain } \\
\text { International } \\
\text { Airport, } \\
\text { Bahrain }\end{array}$ & $143(143)$ & $\begin{array}{c}\text { Approach (During } \\
\text { a Go-Around) }\end{array}$ & \begin{tabular}{|} 
Inappropriate control \\
input by crew \\
resulting from spatial \\
disorientation (which \\
caused pilot to \\
falsely perceive \\
aircraft was pitching \\
up and to input a \\
nose down \\
command)
\end{tabular} & $\begin{array}{l}\text { Human Factors - } \\
\text { Inappropriate crew } \\
\text { response }\end{array}$ & 59 \\
\hline $3 / 30 / 2000$ & $\begin{array}{l}\text { B767, } \\
\text { N182DN / } \\
\text { Delta } \\
\text { Airlines } \\
\text { (Flt. 106) }\end{array}$ & $\begin{array}{l}\text { New York City, } \\
\text { NY, USA }\end{array}$ & $\begin{array}{c}0 \text { (225 } \\
\text { Injuries) }\end{array}$ & $\begin{array}{l}\text { Takeoff - Initial } \\
\text { Climb }\end{array}$ & \begin{tabular}{|c|} 
Upset caused by \\
Crew Spatial \\
Disorientation under \\
Poor Visibility
\end{tabular} & $\begin{array}{l}\text { Upset, Inappropriate } \\
\text { Crew Input }\end{array}$ & 60 \\
\hline $2 / 27 / 2000$ & $\begin{array}{l}\text { B747, G- } \\
\text { BDXL / } \\
\text { British } \\
\text { Airways } \\
\text { (Flt. 179) }\end{array}$ & $\begin{array}{c}\text { Near Providence, } \\
\text { RI, USA }\end{array}$ & $\begin{array}{c}0 \text { (12 } \\
\text { Serious } \\
\text { Injuries) }\end{array}$ & $\begin{array}{c}\text { Approach - Initial } \\
\text { Descent }\end{array}$ & \begin{tabular}{|c|} 
Possible Autopilot \\
Anomaly Resulting \\
from an \\
Inappropriate \\
maintenance action
\end{tabular} & Autopilot Induced Upset & 61 \\
\hline $2 / 16 / 2000$ & \begin{tabular}{|c|} 
DC-8, \\
N8079U / \\
Emery \\
Worldwide \\
(Flt. 17)
\end{tabular} & $\begin{array}{l}\text { Sacramento, CA } \\
\text { USA }\end{array}$ & $3(3)$ & $\begin{array}{l}\text { Takeoff - Initial } \\
\text { Climb }\end{array}$ & \begin{tabular}{|c|} 
Elevator failure at \\
lift-off caused by an \\
improper \\
maintenance action \\
(Loss of pitch control \\
resulting from the \\
disconnection of the \\
right elevator control \\
tab)
\end{tabular} & $\begin{array}{l}\text { Flight Control System } \\
\text { Failure }\end{array}$ & 62 \\
\hline $1 / 31 / 2000$ & $\begin{array}{l}\text { MD-83 } \\
\text { N963AS / } \\
\text { Alaska } \\
\text { Airlines } \\
\text { (Flt 261) }\end{array}$ & $\begin{array}{c}\sim 2.7 \text { Miles } \mathrm{N} \text { of } \\
\text { Anacapa Island, } \\
\text { CA } \\
\text { USA }\end{array}$ & $88(88)$ & Cruise & \begin{tabular}{|c|} 
Failure of Horizontal \\
Stabilizer Trim \\
System Jackscrew \\
Assembly (Improper \\
Maintenance)
\end{tabular} & $\begin{array}{l}\text { Flight Control System } \\
\text { Failure }\end{array}$ & 63 \\
\hline $1 / 10 / 2000$ & $\begin{array}{c}\text { Saab 340B, } \\
\text { HB-AKK / } \\
\text { Crossair } \\
\text { (Flt 498) }\end{array}$ & $\begin{array}{l}\text { Near Nassenwil, } \\
\text { Switzerland }\end{array}$ & $10(10)$ & Takeoff - Climb & $\begin{array}{c}\text { Vehicle upset (spiral } \\
\text { dive) due to spatial } \\
\text { disorientation of } \\
\text { crew }\end{array}$ & \begin{tabular}{|c|} 
Human Factors - \\
Inappropriate crew \\
response due to Spatial \\
Disorientation
\end{tabular} & 64 \\
\hline $12 / 22 / 1999$ & \begin{tabular}{|c|} 
B747, \\
HL7451 / \\
Korean Air \\
(Flt. 8509)
\end{tabular} & $\begin{array}{c}\text { Near Great } \\
\text { Hallingbury, } \\
\text { United Kingdom }\end{array}$ & $4(4)$ & $\begin{array}{l}\text { Takeoff - Initial } \\
\text { Climb }\end{array}$ & \begin{tabular}{c|} 
Vehicle Upset \\
During Initial Climb \\
Resulting from \\
Instrument Failure
\end{tabular} & $\begin{array}{l}\text { System \& Component } \\
\text { Failure }\end{array}$ & 65 \\
\hline 10/18/1999 & \begin{tabular}{|c|} 
Saab SF-340, \\
SE-LES / \\
GAO \\
(Flt 750)
\end{tabular} & & 0 & & $\begin{array}{l}\text { Autopilot-Induced } \\
\text { Stall under Icing } \\
\text { Conditions }\end{array}$ & Stall, Icing & 66 \\
\hline
\end{tabular}

29

American Institute of Aeronautics and Astronautics 


\begin{tabular}{|c|c|c|c|c|c|c|c|}
\hline 4/7/1999 & $\begin{array}{l}\text { B737, TC- } \\
\text { JEP / } \\
\text { Turk Hava } \\
\text { Yollari }\end{array}$ & $\begin{array}{l}\text { Near Ceyhan, } \\
\text { Turkey }\end{array}$ & $6(6)$ & Takeoff - Climb & $\begin{array}{c}\text { Stall due to Icing, } \\
\text { Erratic Airspeed } \\
\text { Indication - Possibly } \\
\text { due to icing of } \\
\text { pitot static tube }\end{array}$ & Stall, Icing & 67 \\
\hline 11/11/1998 & $\begin{array}{l}\text { Saab 340B, } \\
\text { VH-LPI / } \\
\text { Kendell } \\
\text { Airlines }\end{array}$ & $\begin{array}{c}\text { Eildon Weir, VIC } \\
\text { Australia }\end{array}$ & 0 & Holding Pattern & Stall due to Icing & Stall, Icing & 68 \\
\hline 6/16/1998 & $\begin{array}{l}\text { Saab 340, } \\
\text { SE-LEP / } \\
\text { GAO } \\
\text { (Flt. 758) }\end{array}$ & & 0 & & $\begin{array}{l}\text { Autopilot-Induced } \\
\text { Stall under Icing } \\
\text { Conditions }\end{array}$ & Stall, Icing & 69 \\
\hline 2/16/1998 & $\begin{array}{l}\text { A300, B- } \\
1814 \text { / } \\
\text { China } \\
\text { Airlines } \\
\text { (Flt. 676) }\end{array}$ & $\begin{array}{l}\text { Taipei, } \\
\text { Taiwan }\end{array}$ & $\begin{array}{l}196(196) \\
+7 \text { on } \\
\text { ground }\end{array}$ & $\begin{array}{l}\text { Approach - } \\
\text { During Go- } \\
\text { Around }\end{array}$ & $\begin{array}{l}\text { Autopilot-Induced } \\
\text { Stall }\end{array}$ & Autopilot & 70 \\
\hline 10/10/1997 & $\begin{array}{l}\text { DC-9-32, } \\
\text { LV-WEG / } \\
\text { Austral } \\
\text { Lineas } \\
\text { Aereas } \\
\text { (Flt. 2553) }\end{array}$ & $\begin{array}{l}\text { Near Nuevo } \\
\text { Berlin, } \\
\text { Uruguay }\end{array}$ & $74(74)$ & $\begin{array}{l}\text { Cruise / Initial } \\
\text { Descent }\end{array}$ & \begin{tabular}{|} 
Vehicle Upset \\
(uncontrolled \\
descent) due to High- \\
Speed Slat/Flap \\
Extension by Crew \\
Causing Vehicle \\
Asymmetry, Possibly \\
Exacerbated by \\
Weather (Wind \\
Shear) Conditions
\end{tabular} & $\begin{array}{c}\text { Flight Control System } \\
\text { Configuration } \\
\text { Asymmetry }\end{array}$ & 71 \\
\hline 5/12/1997 & $\begin{array}{c}\text { A300, } \\
\text { N90070/ } \\
\text { American } \\
\text { Airlines } \\
\text { (Flt. 903) }\end{array}$ & $\begin{array}{l}\text { West Palm } \\
\text { Beach, FL } \\
\text { USA }\end{array}$ & 0 & $\begin{array}{c}\text { Approach - Initial } \\
\text { Descent }\end{array}$ & \begin{tabular}{|c|} 
Improper Use of \\
Autothrottle by Crew \\
which resulted in \\
loss of airspeed and \\
stall, Forces during \\
the upset exceeded \\
the design limit for \\
the vertical tail
\end{tabular} & Stall & 72 \\
\hline 1/9/1997 & \begin{tabular}{|c} 
Embraer-120 \\
$/$ \\
Comair/Delta \\
Connection \\
(Flt 3272)
\end{tabular} & $\begin{array}{c}\text { Near Monroe, MI } \\
\text { USA }\end{array}$ & 29 (29) & Approach & $\begin{array}{c}\text { Uncontrolled descent } \\
\text { following icing } \\
\text { encounter }\end{array}$ & Icing, stall & 73 \\
\hline $12 / 22 / 1996$ & $\begin{array}{l}\text { DC-8 / } \\
\text { Airborne } \\
\text { Express } \\
\text { (Flt. 827) }\end{array}$ & $\begin{array}{l}6.5 \mathrm{~km} \mathrm{~W} \text { of } \\
\text { Narrows, VA } \\
\text { USA }\end{array}$ & $6(6)$ & Cruise & $\begin{array}{c}\text { Stall Followed by } \\
\text { Falling Leaf Upset, } \\
\text { Inappropriate } \\
\text { Control Inputs for } \\
\text { Stall Recovery, } \\
\text { Inoperative Stall } \\
\text { Warning System }\end{array}$ & \begin{tabular}{|l|} 
Inappropriate crew \\
training for stall recovery \\
(inadequate training \\
simulator fidelity in \\
reproducing airplane's \\
stall characteristics)
\end{tabular} & 74 \\
\hline
\end{tabular}

30

American Institute of Aeronautics and Astronautics 


\begin{tabular}{|c|c|c|c|c|c|c|c|}
\hline |10/31/1996 & \begin{tabular}{|} 
Fokker 100, \\
PT-MRK / \\
TAM Brasil \\
(Flt. 402)
\end{tabular} & $\begin{array}{l}\text { Congonhas } \\
\text { Airport, } \\
\text { Sao Paulo, } \\
\text { Brazil }\end{array}$ & $\begin{array}{l}95 \text { (95) } \\
+4 \text { on } \\
\text { Ground }\end{array}$ & \begin{tabular}{|c} 
Takeoff - Aircraft \\
Failed to Gain \\
Altitude \& \\
Collided with Tall \\
Building
\end{tabular} & \begin{tabular}{|} 
Stall Resulting from \\
Inadvertent \\
Deployment of \\
Thrust Reverser on \\
No. 2 Engine \\
resulting in \\
Asymmetric Forces \\
on Aircraft \\
\end{tabular} & $\begin{array}{c}\text { Stall - Engine } \\
\text { Impairment Resulting } \\
\text { from Inadvertent } \\
\text { Deployment of Thrust } \\
\text { Reverser }\end{array}$ & 75 \\
\hline 6/9/1996 & $\begin{array}{l}\text { B737-200, } \\
\text { N221US / } \\
\text { Eastwind } \\
\text { Airlines } \\
\text { (Flt. 517) }\end{array}$ & $\begin{array}{c}\text { Near Richmond, } \\
\text { VA } \\
\text { USA }\end{array}$ & $\begin{array}{c}0 \\
\text { (Incident) }\end{array}$ & Approach & $\begin{array}{c}\text { Rudder System } \\
\text { Malfunction (Rudder } \\
\text { Reversal) }\end{array}$ & $\begin{array}{c}\text { Flight Control System } \\
\text { Failure }\end{array}$ & 76 \\
\hline 2/6/1996 & $\begin{array}{l}\text { B757-200, } \\
\text { TC-GEN / } \\
\text { Birgenair } \\
\text { (Flt. 301) }\end{array}$ & $\begin{array}{l}26 \text { km NE off } \\
\text { Puerto Plata, } \\
\text { Dominican } \\
\text { Republic }\end{array}$ & 189 (189) & Takeoff & \begin{tabular}{|c} 
Aircraft Stall \\
Resulting from \\
Faulty \\
Instrumentation \\
(Blocked Pitot Tube \\
Resulting in \\
Erroneous Airspeed \\
Readings to \\
Autopilot and Pilot), \\
Poor Situational \\
Awareness and \\
Reaction by Crew to \\
Faulty Airspeed \\
Indicator \\
\end{tabular} & $\begin{array}{l}\text { Flight Control System } \\
\text { Failure }\end{array}$ & 77 \\
\hline 2/4/1996 & $\begin{array}{l}\text { DC-8, HK- } \\
\text { 3979X / } \\
\text { LAC } \\
\text { Colombia } \\
\text { (Cargo) }\end{array}$ & $\begin{array}{c}2 \mathrm{~km} \mathrm{~N} \text { of } \\
\text { Asuncion-Silvo } \\
\text { Pettirossi } \\
\text { International } \\
\text { Airport, } \\
\text { Paraguay }\end{array}$ & $\begin{array}{c}4(4) \\
+20 \text { on } \\
\text { Ground }\end{array}$ & $\begin{array}{c}\text { Takeoff - Initial } \\
\text { Climb }\end{array}$ & $\begin{array}{c}2 \text { Engines Throttled } \\
\text { Back on Same Wing } \\
\text { During Unauthorized } \\
\text { Single Engine-Out } \\
\text { Training (Gear } \\
\text { Down and Flaps at } \\
15 \mathrm{deg})\end{array}$ & $\begin{array}{c}\text { Vehicle upset } \\
\text { (asymmetric forces and } \\
\text { reduced airspeed) Due to } \\
\text { Unauthorized Engine } \\
\text { Throttle Back }\end{array}$ & 78 \\
\hline 12/3/1995 & $\begin{array}{l}\text { B737-200, } \\
\text { TJ-CB / } \\
\text { Cameroon } \\
\text { Airlines }\end{array}$ & $\begin{array}{c}\text { Douala, } \\
\text { Cameroon }\end{array}$ & $71(76)$ & $\begin{array}{l}\text { Approach / Go- } \\
\text { Around }\end{array}$ & $\begin{array}{l}\text { Engine Failure on } \\
\text { Go-Around }\end{array}$ & $\begin{array}{l}\text { Flight Control System } \\
\text { Failure - Engines }\end{array}$ & 79 \\
\hline 4/27/1995 & $\begin{array}{c}\text { A320, } \\
\text { N331NW / } \\
\text { Northwest } \\
\text { Airlines } \\
\text { (Flt. 352) }\end{array}$ & $\begin{array}{c}\text { Washington D.C., } \\
\text { USA }\end{array}$ & 0 & Visual Approach & $\begin{array}{c}\text { Inappropriate control } \\
\text { input by crew (PIO) } \\
\text { in response to wind } \\
\text { gusts }\end{array}$ & $\mathrm{PIO}$ & 80 \\
\hline 3/31/1995 & $\begin{array}{l}\text { A310, YR- } \\
\text { LCC / } \\
\text { Tarom } \\
\text { (Flt. 371) }\end{array}$ & $\begin{array}{l}\text { Near Balotesti, } \\
\text { Romania }\end{array}$ & $60(60)$ & Takeoff / Climb & $\begin{array}{c}\text { Engine Failed to } \\
\text { Advance Resulting } \\
\text { in Thrust } \\
\text { Asymmetry, Possible } \\
\text { Pilot Incapacitation }\end{array}$ & Engine Failure & 81 \\
\hline $12 / 13 / 1994$ & \begin{tabular}{|c|} 
Jetstream 32, \\
N918AE / \\
American \\
Eagle \\
(Flt. 3379)
\end{tabular} & $\begin{array}{c}7.4 \mathrm{~km} \mathrm{SW} \text { of } \\
\text { Raleigh/Gurham } \\
\text { Airport, NC } \\
\text { USA }\end{array}$ & $15(20)$ & Approach & $\begin{array}{c}\text { Inappropriate Crew } \\
\text { Response to } \\
\text { Possible Engine } \\
\text { Failure on Approach } \\
\text { and Ineffective Stall } \\
\text { Recovery }\end{array}$ & \begin{tabular}{|c|} 
Vehicle Stall Resulting \\
from Inappropriate Crew \\
Control Inputs \\
\end{tabular} & 82 \\
\hline
\end{tabular}




\begin{tabular}{|c|c|c|c|c|c|c|c|}
\hline |12/11/1994| & $\begin{array}{l}\text { B737, } \\
\text { N681MA / } \\
\text { Markair } \\
\text { (Flt. 308) }\end{array}$ & $\begin{array}{c}\text { Anchorage, } \\
\text { Alaska USA }\end{array}$ & 0 & Climb & $\begin{array}{l}\text { Vehicle Upset } \\
\text { Resulting from } \\
\text { Autopilot Elevator } \\
\text { Actuator Failure }\end{array}$ & $\begin{array}{c}\text { Flight Control System } \\
\text { Failure }\end{array}$ & 83 \\
\hline 10/31/1994 & $\begin{array}{c}\text { ATR-72, } \\
\text { N401AM / } \\
\text { American } \\
\text { Eagle } \\
\text { (Flt 4184) }\end{array}$ & $\begin{array}{c}\text { Near Roselawn, } \\
\text { IN } \\
\text { USA }\end{array}$ & $68(68)$ & $\begin{array}{l}\text { Approach - } \\
\text { Holding }\end{array}$ & \begin{tabular}{|c|} 
Vehicle Impairment \\
under Icing \\
Conditions Resulting \\
in Aircraft Stall \\
(Sudden and \\
Unexpected Aileron \\
Hinge Moment \\
Reversal Resulting \\
from Contaminated \\
Airfoil) \\
\end{tabular} & Icing, stall & 84 \\
\hline 9/8/1994 & $\begin{array}{l}\text { B737-300 } \\
\text { N513AU / } \\
\text { USAir (Flt } \\
427)\end{array}$ & $\begin{array}{l}\text { Near Pittsburg, } \\
\text { PA (Aliquippa) } \\
\text { USA }\end{array}$ & 132 (132) & Approach & \begin{tabular}{|c|} 
Vehicle stall \\
resulting from \\
Rudder System \\
Failure (rudder \\
reversal) subsequent \\
to a wake encounter \\
\end{tabular} & $\begin{array}{c}\text { Flight Control System } \\
\text { Failure, Stall }\end{array}$ & 85 \\
\hline $7 / 2 / 1994$ & $\begin{array}{c}\text { DC-9, } \\
\text { N954VJ / } \\
\text { USAir } \\
\text { (Flt. 1016) }\end{array}$ & $\begin{array}{c}\text { Charlotte- } \\
\text { Douglas } \\
\text { International } \\
\text { Airport, NC, } \\
\text { USA }\end{array}$ & 37 (57) & $\begin{array}{l}\text { Approach - } \\
\text { During Go- } \\
\text { Around }\end{array}$ & \begin{tabular}{|c|} 
Vehicle stall \\
resulting from wind \\
shear encounter, \\
Failure of Wind \\
Shear Warning \\
System to Activate \\
(Due to inadequate \\
software logic), \\
Thrust Setting was \\
below standard go- \\
around EPR limit of \\
1.93
\end{tabular} & $\begin{array}{c}\text { Atmospheric } \\
\text { Disturbance, Wind } \\
\text { Shear, Resulting in Stall }\end{array}$ & 86 \\
\hline 6/29/1994 & $\begin{array}{l}\text { MD-11, } \\
\text { N1752K / } \\
\text { American } \\
\text { Airlines } \\
\text { (Flt. 901) }\end{array}$ & $\begin{array}{c}\text { Over the } \\
\text { Caribbean Sea, } \\
\text { South of Cuba }\end{array}$ & $\begin{array}{c}0 \\
\text { (1 Serious } \\
\text { Injury) }\end{array}$ & Cruise & \begin{tabular}{|c|} 
Vehicle Upset \\
Resulting from \\
Inappropriate \\
Control Input by \\
Crew (Unintended \\
Control Column \\
Input resulting from \\
inadvertent \\
movement of the first \\
officer's seat)
\end{tabular} & $\begin{array}{c}\text { Inappropriate/Inadvertent } \\
\text { Control Input by Crew } \\
\end{array}$ & 87 \\
\hline $4 / 26 / 1994$ & $\begin{array}{l}\text { A300, B- } \\
\text { 1816 / } \\
\text { China } \\
\text { Airlines } \\
\text { (Flt. 140) }\end{array}$ & $\begin{array}{c}\text { Nagoya-Komaki, } \\
\text { Japan }\end{array}$ & $264(271)$ & Approach & \begin{tabular}{|c|} 
Vehicle Stalled as a \\
result of inadvertent \\
control setting on \\
approach \\
(Inadvertent \\
Engagement of Take \\
Off Go Around \\
(TOGA) Mode) and \\
Abnormal Out-of- \\
Trim Condition \\
\end{tabular} & $\begin{array}{c}\text { Stall, Inappropriate } \\
\text { control input by crew }\end{array}$ & 88 \\
\hline
\end{tabular}




\begin{tabular}{|c|c|c|c|c|c|c|c|}
\hline 3/23/1994 & \begin{tabular}{|c|} 
A310, F- \\
OGQS / \\
Aeroflot \\
Russian \\
International \\
Airlines \\
(Flt. 593)
\end{tabular} & $\begin{array}{c}\text { Near } \\
\text { Mezhduretshensk, } \\
\text { Russia } \\
\end{array}$ & $75(75)$ & Cruise & $\begin{array}{c}\text { Aircraft stalled as a } \\
\text { result of inadvertent } \\
\text { partial } \\
\text { disengagement of } \\
\text { autopilot } \\
\text { (unauthorized person } \\
\text { in cockpit } \\
\text { inadvertently } \\
\text { disabled autopilot's } \\
\text { control of the } \\
\text { ailerons) }\end{array}$ & Stall, Mode Confusion & 89 \\
\hline $3 / 8 / 1994$ & \begin{tabular}{|c|} 
B737, VT- \\
SIA / Sahara \\
India \\
Airlines
\end{tabular} & $\begin{array}{l}\text { Delhi-Indira } \\
\text { Ghandi } \\
\text { International } \\
\text { Airport, } \\
\text { India }\end{array}$ & $\begin{array}{l}4(4) \\
+4 \text { on } \\
\text { ground }\end{array}$ & $\begin{array}{c}\text { Takeoff } \\
\text { (Training Flight) }\end{array}$ & \begin{tabular}{|c|} 
Inappropriate \\
Control Input by \\
Crew (Trainee Pilot \\
Applied Incorrect \\
Rudder Input During \\
Engine Failure \\
Exercise)
\end{tabular} & $\begin{array}{c}\text { Loss of control resulting } \\
\text { from inappropriate } \\
\text { control input }\end{array}$ & 90 \\
\hline 1/7/1994 & \begin{tabular}{|c|} 
Jetstream 41, \\
N304UE / \\
United \\
Express \\
(Flt. 6291)
\end{tabular} & $\begin{array}{l}1.9 \text { km E of } \\
\text { Columbus } \\
\text { International } \\
\text { Airport, } \\
\text { Ohio, USA }\end{array}$ & $5(9)$ & Approach & \begin{tabular}{|c|} 
Aircraft stall on final \\
approach, possibly \\
under icing \\
conditions
\end{tabular} & Stall & 91 \\
\hline $12 / 15 / 1993$ & $\begin{array}{l}\text { IAI-1124, } \\
\text { N309CK / } \\
\text { Martin } \\
\text { Aviation }\end{array}$ & $\begin{array}{c}6.5 \mathrm{~km} \mathrm{~N} \text { of Santa } \\
\text { Ana, CA } \\
\text { USA }\end{array}$ & $5(5)$ & Approach & $\begin{array}{l}\text { Loss of control } \\
\text { resulting from } \\
\text { atmospheric } \\
\text { disturbance }\end{array}$ & $\begin{array}{c}\text { Atmospheric } \\
\text { Disturbance, Wake }\end{array}$ & 92 \\
\hline 8/18/1993 & $\begin{array}{c}\text { DC-8, } \\
\text { N814CK / } \\
\text { Kalitta } \\
\text { International } \\
\text { (Flt. 808) }\end{array}$ & $\begin{array}{l}\text { Guantanamo, } \\
\text { Cuba }\end{array}$ & 0 & Approach & $\begin{array}{l}\text { Vehicle stalled on } \\
\text { final approach } \\
\text { coupled with flight } \\
\text { crew fatigue }\end{array}$ & Stall & 93 \\
\hline 4/29/1993 & $\begin{array}{c}\text { Embraer 120, } \\
\text { N24706 / } \\
\text { Continental } \\
\text { Express } \\
\text { (Flt. 2733) }\end{array}$ & $\begin{array}{c}\text { Pine Bluff, AR } \\
\text { USA }\end{array}$ & 0 & Climb & $\begin{array}{l}\text { Autopilot-induced } \\
\text { stall, Crew Fatigue, } \\
\text { Possible PIO }\end{array}$ & Stall & 94 \\
\hline 4/7/1993 & \begin{tabular}{|c|} 
B757, C- \\
FOOA / \\
Canada 3000 \\
Airline \\
Charter (Elite \\
Flt. 833)
\end{tabular} & $\begin{array}{c}30 \text { miles S of } \\
\text { Houston, TX } \\
\text { USA }\end{array}$ & 0 & Cruise & \begin{tabular}{|c|} 
In-flight upset as a \\
result of extreme \\
turbulence and \\
system failure \\
(Aircraft generators \\
came off-line with \\
loss of power to all \\
flight, navigation, \\
and engine \\
instruments) \\
\end{tabular} & $\begin{array}{c}\text { Atmospheric } \\
\text { Disturbance, Turbulence }\end{array}$ & 95 \\
\hline $4 / 6 / 1993$ & $\begin{array}{l}\text { MD-11, B- } \\
2171 \text { / } \\
\text { China } \\
\text { Eastern } \\
\text { Airlines } \\
\text { (Flt. 583) }\end{array}$ & $\begin{array}{l}1760 \mathrm{~km} \mathrm{~S} \text { of } \\
\text { Shemya, AK } \\
\text { USA }\end{array}$ & 2 (255) & Cruise & \begin{tabular}{|} 
In-flight upset as a \\
result of inadvertent \\
slat deployment \\
during cruise, Large \\
Load Factor \\
Excursions Resulting \\
in Structural Damage
\end{tabular} & \begin{tabular}{|c|} 
Vehicle Upset, \\
Inappropriate / \\
Inadvertent Control Input \\
\end{tabular} & 96 \\
\hline
\end{tabular}




\begin{tabular}{|c|c|c|c|c|c|c|c|}
\hline 3/5/1993 & $\begin{array}{c}\text { Fokker 100, } \\
\text { PH-KXL / } \\
\text { Palair } \\
\text { Macedonian } \\
\text { (Flt. 301) }\end{array}$ & $\begin{array}{l}\text { Skopje Airport, } \\
\text { Macedonia }\end{array}$ & 83 (97) & $\begin{array}{l}\text { Takeoff - Initial } \\
\text { Climb }\end{array}$ & $\begin{array}{c}\text { Loss of roll } \\
\text { controllability due to } \\
\text { contaminated wing } \\
\text { resulting from icing }\end{array}$ & $\begin{array}{c}\text { Icing - Contaminated } \\
\text { Airfoil }\end{array}$ & 97 \\
\hline $3 / 4 / 1993$ & \begin{tabular}{|c|} 
Aerospatiale \\
ATR-42, \\
N99838 / \\
Britt Airways \\
(Flt 3444)
\end{tabular} & $\begin{array}{c}\text { Near Newark } \\
\text { International } \\
\text { Airport, NJ } \\
\text { USA }\end{array}$ & 0 & Approach & $\begin{array}{c}\text { Loss of roll control } \\
\text { due to contaminated } \\
\text { wing resulting from } \\
\text { icing }\end{array}$ & $\begin{array}{c}\text { Icing - Contaminated } \\
\text { Airfoil }\end{array}$ & 98 \\
\hline 12/7/1992 & \begin{tabular}{|c|} 
MD-11, B- \\
150 / China \\
Airlines \\
(Flt. 012)
\end{tabular} & $\begin{array}{c}\text { Near Kushimoto, } \\
\text { Japan }\end{array}$ & 0 & Cruise & \begin{tabular}{|c|} 
Vehicle upset \\
resulting from \\
turbulence, \\
Excessive control \\
inputs by pilot, \\
Damage sustained to \\
left and right \\
outboard elevator \\
resulting in loss of \\
portions of these \\
surfaces
\end{tabular} & \begin{tabular}{|c|} 
Atmospheric \\
Disturbance - Turbulence \\
\end{tabular} & 99 \\
\hline $6 / 6 / 1992$ & $\begin{array}{l}\text { B737-204 } \\
\text { HP-120 / } \\
\text { COPA } \\
\text { Airlines }\end{array}$ & $\begin{array}{l}\text { Tucuti, } \\
\text { Panama }\end{array}$ & 47 (47) & & \begin{tabular}{|c|} 
Uncontrolled \\
Descent resulting \\
from instrumentation \\
fault/failure \\
(Incorrect Bank \\
Indication)
\end{tabular} & \begin{tabular}{|c|} 
Uncontrolled Descent, \\
Flight control component \\
failure
\end{tabular} & 100 \\
\hline $3 / 22 / 1992$ & \begin{tabular}{|c|} 
Fokker F-28, \\
N485US / \\
USAir \\
(Flt. 405)
\end{tabular} & $\begin{array}{c}\text { New York } \\
\text { La Guardia } \\
\text { Airport, NY, } \\
\text { USA }\end{array}$ & $27(51)$ & $\begin{array}{l}\text { Takeoff - Initial } \\
\text { Climb }\end{array}$ & $\begin{array}{c}\text { Vehicle stalled as a } \\
\text { result of icing } \\
\text { conditions }\end{array}$ & Stall / Icing & 101 \\
\hline 2/15/1992 & \begin{tabular}{|c|} 
DC-8, \\
N794AL / \\
Air Transport \\
Internation \\
(ATI) \\
(Flt. 805)
\end{tabular} & $\begin{array}{c}5 \text { km NW of } \\
\text { Toledo-Express } \\
\text { Airport, OH } \\
\text { USA }\end{array}$ & $4(4)$ & Approach & $\begin{array}{l}\text { Vehicle upset } \\
\text { resulting from } \\
\text { possible crew } \\
\text { disorientation or } \\
\text { instrumentation } \\
\text { failure (attitude } \\
\text { director) }\end{array}$ & $\begin{array}{l}\text { Vehicle Upset - } \\
\text { Unusual Attitudes }\end{array}$ & 102 \\
\hline 9/18/1991 & $\begin{array}{c}\text { Convair CV- } \\
580, \text { C-FICA } \\
/ \\
\text { Canair Cargo }\end{array}$ & \begin{tabular}{|c|} 
Belvedere Center, \\
VT, USA
\end{tabular} & $2(2)$ & Cruise & \begin{tabular}{|c|} 
Vehicle upset \\
resulting from spatial \\
disorientation, \\
In-flight break-up \\
resulting from \\
exceedance of design \\
stress limits of the \\
aircraft
\end{tabular} & $\begin{array}{c}\text { Vehicle upset - spatial } \\
\text { disorientation }\end{array}$ & 103 \\
\hline 9/11/1991 & \begin{tabular}{|c|} 
Embraer 120, \\
N33701 / \\
Jet Link - \\
Continental \\
Express \\
(Flt. 2574)
\end{tabular} & $\begin{array}{c}\text { Eagle Lake, TX } \\
\text { USA }\end{array}$ & $14(14)$ & Cruise & \begin{tabular}{|c|} 
Vehicle upset \\
resulting from \\
airframe damage \\
(In-flight separation \\
of the left horizontal \\
stabilizer leading \\
edge resulting from \\
improper \\
maintenance to \\
replace the de-ice \\
boots)
\end{tabular} & $\begin{array}{l}\text { Vehicle upset - airframe } \\
\text { damage }\end{array}$ & 104 \\
\hline
\end{tabular}

34

American Institute of Aeronautics and Astronautics 


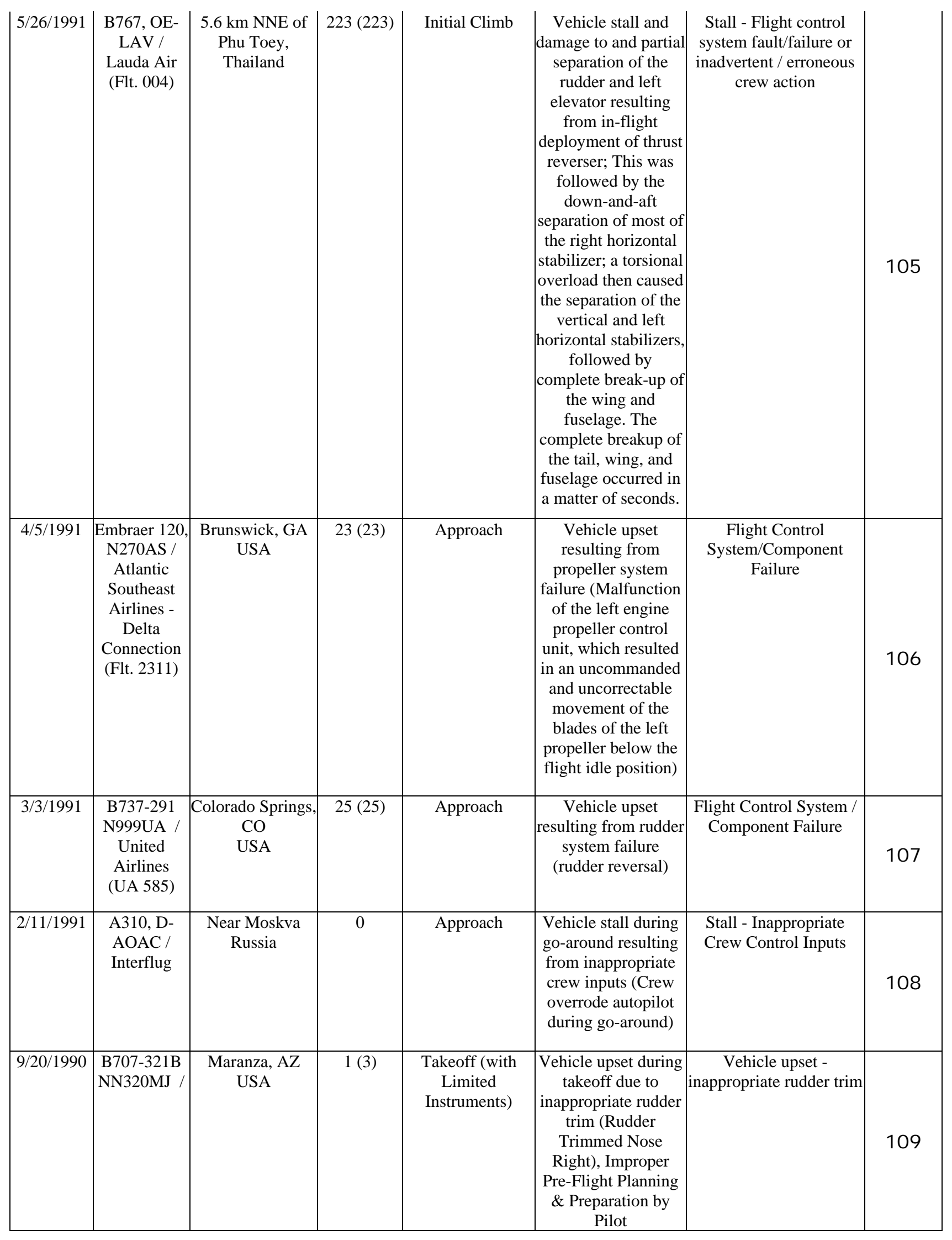

35

American Institute of Aeronautics and Astronautics 


\begin{tabular}{|c|c|c|c|c|c|c|c|}
\hline 7/19/1989 & $\begin{array}{l}\text { DC-10-10 } \\
\text { N1819U / } \\
\text { United } \\
\text { Airlines } \\
\text { (Flt 232) }\end{array}$ & $\begin{array}{c}\text { Sioux City, Iowa } \\
\text { USA }\end{array}$ & 111 (296) & Cruise & $\begin{array}{l}\text { Uncontained engine } \\
\text { failure resulting in } \\
\text { vehicle damage and } \\
\text { loss of hydraulics to } \\
\text { control surfaces, } \\
\text { Pilot Used } \\
\text { Differential Engines } \\
\text { to Crash Land Near } \\
\text { Sioux City Gateway } \\
\text { Airport }\end{array}$ & $\begin{array}{c}\text { Flight control } \\
\text { system/component } \\
\text { failure }\end{array}$ & 110 \\
\hline 3/10/1989 & \begin{tabular}{|c|} 
Fokker F-18, \\
C-FONF / \\
Air Ontario \\
(Flt. 1363)
\end{tabular} & $\begin{array}{c}\text { Dryden } \\
\text { Municipal } \\
\text { Airport, ON } \\
\text { Canada }\end{array}$ & 24 (69) & $\begin{array}{c}\text { Takeoff - Initial } \\
\text { Climb }\end{array}$ & $\begin{array}{l}\text { Aircraft was unable } \\
\text { to gain altitude due } \\
\text { to contaminated } \\
\text { airfoil from icing }\end{array}$ & $\begin{array}{c}\text { Icing - Contaminated } \\
\text { Airfoil }\end{array}$ & 111 \\
\hline 1/8/1989 & $\begin{array}{l}\text { B737, G- } \\
\text { OBME / } \\
\text { British } \\
\text { Midland } \\
\text { Airways } \\
\text { (Flt. 092) }\end{array}$ & \begin{tabular}{|c|} 
Kegworth, \\
United Kingdom \\
Near East \\
Midlands
\end{tabular} & 47 (126) & Approach & $\begin{array}{c}\text { Engine Failure } \\
\text { Combined with } \\
\text { Inappropriate Crew } \\
\text { Response (Crew } \\
\text { Shut Down Wrong } \\
\text { Engine ) }\end{array}$ & Engine Failure & 112 \\
\hline 9/15/1988 & $\begin{array}{l}\text { B737, ET- } \\
\text { AJA / } \\
\text { Ethiopian } \\
\text { Airlines } \\
\text { (Flt. 604) }\end{array}$ & $\begin{array}{l}10 \text { km SW of } \\
\text { Bahar Dar } \\
\text { Airport, } \\
\text { Ethiopia }\end{array}$ & 35 (104) & Takeoff & $\begin{array}{c}\text { Loss of both engines } \\
\text { due to ingestion of } \\
\text { foreign objects } \\
\text { (birds) }\end{array}$ & Engine Damage & 113 \\
\hline $2 / 9 / 1988$ & \begin{tabular}{|c|} 
Jetstream 31, \\
N823JS / \\
Jetstream \\
International \\
- Piedmont \\
Commuter
\end{tabular} & $\begin{array}{l}\text { Springfield } \\
\text { Airport, OH, } \\
\text { USA }\end{array}$ & $3(3)$ & $\begin{array}{l}\text { Approach - } \\
\text { During Go- } \\
\text { Around }\end{array}$ & \begin{tabular}{|c|} 
Loss of control \\
resulting from \\
inappropriate vehicle \\
configuration during \\
go-around; \\
Insufficient \\
supervision during \\
training flight
\end{tabular} & $\begin{array}{c}\text { Vehicle Impairment - } \\
\text { Inappropriate Vehicle } \\
\text { Configuration }\end{array}$ & 114 \\
\hline 8/31/1987 & \begin{tabular}{|c|} 
B737, HS- \\
TBC / \\
Thai Airways \\
(Flt. 365)
\end{tabular} & $\begin{array}{c}15 \text { km off Phuket, } \\
\text { Thailand }\end{array}$ & $83(83)$ & Approach & $\begin{array}{c}\text { Vehicle stalled on } \\
\text { final approach, Pilot } \\
\text { distracted by traffic } \\
\text { pattern on approach } \\
\text { and did not execute a } \\
\text { recovery in time to } \\
\text { save the vehicle }\end{array}$ & Stall & 115 \\
\hline $3 / 4 / 1987$ & \begin{tabular}{|c|} 
CASA C- \\
212, N160FB \\
$/$ \\
Northwest \\
Airlink \\
(Flt. 2268)
\end{tabular} & $\begin{array}{c}\text { Detroit } \\
\text { Metropolitan } \\
\text { Wayne County } \\
\text { Airport, MI } \\
\text { USA }\end{array}$ & $9(19)$ & Final Approach & \begin{tabular}{|c|} 
Vehicle upset \\
resulting from \\
inappropriate control \\
inputs by Crew \\
(Asymmetric power \\
condition at low \\
speed following \\
pilot's intentional use \\
of beta mode of \\
propeller operation \\
to descend and slow \\
the airplane rapidly \\
on final approach)
\end{tabular} & $\begin{array}{l}\text { Inappropriate Control } \\
\text { Input by Crew }\end{array}$ & 116 \\
\hline
\end{tabular}




\begin{tabular}{|c|c|c|c|c|c|c|c|}
\hline 9/6/1985 & $\begin{array}{l}\text { DC-9-14 } \\
\text { N100ME / } \\
\text { Midwest } \\
\text { Express } \\
\text { (Flt 105) }\end{array}$ & $\begin{array}{c}\text { Milwaukee, WI } \\
\text { USA }\end{array}$ & $31(31)$ & Takeoff & \begin{tabular}{|} 
Vehicle stall \\
resulting from engine \\
failure and \\
inappropriate crew \\
response (Pilot Input \\
Incorrect Rudder \\
Command) \\
\end{tabular} & Engine, stall & 117 \\
\hline 8/12/1985 & $\begin{array}{l}\text { B747, } \\
\text { JA8119 / } \\
\text { Japan Air } \\
\text { Lines } \\
\text { (Flt. 123) }\end{array}$ & $\begin{array}{l}\text { Near Ueno } \\
\text { Japan }\end{array}$ & $520(524)$ & Cruise & \begin{tabular}{|} 
Airframe damage \\
that resulted in loss \\
of control surfaces \\
(Rupture of aft \\
bulkhead initiated by \\
fatigue cracks, \\
resulting in \\
separation of a \\
portion of the \\
vertical fin and the \\
section of the \\
tailcone that contains \\
the auxiliary power \\
unit; this damage \\
caused a drop in \\
hydraulic pressure, \\
which resulted in the \\
inoperability of the \\
control surfaces)
\end{tabular} & Airframe Failure & 118 \\
\hline $2 / 19 / 1985$ & $\begin{array}{c}\text { B747, } \\
\text { N4522V / } \\
\text { China } \\
\text { Airlines } \\
\text { (Flt. 006) }\end{array}$ & $\begin{array}{c}550 \mathrm{~km} \mathrm{NW} \text { off } \\
\text { San Francisco, } \\
\text { CA } \\
\text { USA }\end{array}$ & $\begin{array}{c}0 \\
\text { (2 Serious } \\
\text { Injuries) }\end{array}$ & Cruise & \begin{tabular}{|c|} 
In-flight upset \\
following engine \\
failure resulting from \\
insufficiency of the \\
autopilot for \\
operation under \\
abnormal conditions; \\
Crew was distracted \\
with the engine \\
failure, relied too \\
heavily on the \\
autopilot, and failed \\
to monitor airplane's \\
flight instruments; \\
Successful recovery \\
and safe landing \\
were made by the \\
crew; Airplane \\
suffered major \\
structural damage \\
during the upset, \\
descent, and \\
subsequent recovery
\end{tabular} & $\begin{array}{l}\text { Flight Control System } \\
\text { Failure - Engines, } \\
\text { Autopilot Insufficiency } \\
\text { for Off-Nominal } \\
\text { Operation }\end{array}$ & 119 \\
\hline
\end{tabular}




\begin{tabular}{|c|c|c|c|c|c|c|c|}
\hline 1/21/1985 & \begin{tabular}{|c|} 
Lockheed L- \\
188 Electra, \\
N5532 / \\
Galaxy \\
Airlines \\
(Flt. 203)
\end{tabular} & $\begin{array}{c}3 \mathrm{~km} \text { SE of Reno } \\
\text { / Tahoe } \\
\text { International } \\
\text { Airport, NV } \\
\text { USA }\end{array}$ & $70(71)$ & $\begin{array}{c}\text { Takeoff - Initial } \\
\text { Climb }\end{array}$ & \begin{tabular}{|c|} 
Aircraft stalled as a \\
result of in-flight \\
vehicle anomaly / \\
damage (Failure of \\
ground crew to \\
secure the air start \\
access door, which \\
caused unexpected \\
"thunking" noise and \\
vibration during \\
takeoff - and possible \\
airframe damage)
\end{tabular} & Stall & 120 \\
\hline 5/30/1984 & \begin{tabular}{|c|} 
Lockheed L- \\
188 Electra, \\
N5523 / \\
Zantop \\
International \\
Airlines \\
(Flt. 931)
\end{tabular} & $\begin{array}{l}\text { Chalkhill, PA } \\
\text { USA }\end{array}$ & $4(4)$ & Cruise & \begin{tabular}{|c|} 
Vehicle upset \\
resulting from \\
instrumentation \\
failure (No. 2 Gyro \\
Malfunction; \\
Possible conflicting \\
pitch and roll \\
information to flight \\
crew), In-flight \\
damage and breakup \\
resulting from \\
overstress during \\
upset and attempted \\
recovery \\
\end{tabular} & $\begin{array}{c}\text { System \& Component } \\
\text { Failure - Instrumentation }\end{array}$ & 121 \\
\hline 7/9/1982 & \begin{tabular}{|r} 
B727, N4737 \\
$/$ American \\
Pan \\
World \\
Airways \\
(Flt. 759)
\end{tabular} & $\begin{array}{c}\text { New Orleans, LA } \\
\text { USA }\end{array}$ & $\begin{array}{l}145(145) \\
+8 \text { on } \\
\text { ground }\end{array}$ & $\begin{array}{l}\text { Takeoff - Initial } \\
\text { Climb }\end{array}$ & $\begin{array}{l}\text { Microburst wind } \\
\text { shear encounter on } \\
\text { takeoff }\end{array}$ & $\begin{array}{c}\text { Atmospheric } \\
\text { Disturbance - Wind } \\
\text { Shear }\end{array}$ & 122 \\
\hline $1 / 13 / 1982$ & $\begin{array}{c}\text { B737, } \\
\text { N62AF / } \\
\text { Air Florida } \\
\text { (Flt. 90) }\end{array}$ & \begin{tabular}{|c|}
$1.4 \mathrm{~km} \mathrm{~N}$ of \\
Washington- \\
National Airport, \\
DC, USA
\end{tabular} & $\begin{array}{l}74(79) \\
+4 \text { on } \\
\text { ground }\end{array}$ & $\begin{array}{l}\text { Takeoff - Initial } \\
\text { Climb }\end{array}$ & $\begin{array}{l}\text { Vehicle stalled as a } \\
\text { result of icing } \\
\text { conditions that } \\
\text { contaminated the } \\
\text { airfoil }\end{array}$ & Stall / Icing & 123 \\
\hline 11/11/1979 & \begin{tabular}{|c|} 
DC-10, XA- \\
DUH / \\
AeroNaves \\
(Flt. 945)
\end{tabular} & $\begin{array}{c}\text { Near Luxemburg, } \\
\text { Germany }\end{array}$ & 0 & $\begin{array}{c}\text { Takeoff - Climb to } \\
\text { Cruise } \\
\end{array}$ & \begin{tabular}{|c|} 
Autopilot-Induced \\
stall in vertical speed \\
mode; Overload \\
failure to elevator \\
assembly \\
attachments (in-flight \\
separation)
\end{tabular} & Stall & 124 \\
\hline
\end{tabular}




\begin{tabular}{|c|c|c|c|c|c|c|c|}
\hline 5/25/1979 & \begin{tabular}{|c|} 
DC-10-10, \\
N110AA / \\
American \\
Airlines (Flt. \\
191)
\end{tabular} & $\begin{array}{c}\text { O’Hare } \\
\text { International } \\
\text { Airport } \\
\text { Chicago, IL } \\
\text { USA }\end{array}$ & $\begin{array}{l}271(271) \\
\quad+2\end{array}$ & $\begin{array}{l}\text { Takeoff (Just } \\
\text { After Rotation) }\end{array}$ & \begin{tabular}{|c|} 
Vehicle stalled as a \\
result of vehicle \\
damage (separation \\
of Left Engine \& \\
Pylon Assembly \& \\
$\sim 3$ ft. of Leading \\
Edge from Left Wing \\
with Uncommanded \\
Retraction of Left \\
Wing Outboard LE \\
Slats (Resulted from \\
Poor Maintenance)); \\
Failure of Stall \\
Warning System
\end{tabular} & Airframe Damage / Stall & 125 \\
\hline $4 / 4 / 1979$ & $\begin{array}{c}\text { B727, } \\
\text { N840TW / } \\
\text { Trans World } \\
\text { Airlines } \\
\text { (Flt. 841) }\end{array}$ & $\begin{array}{l}\text { Near Saginaw, } \\
\text { MI USA }\end{array}$ & 0 & Cruise & \begin{tabular}{|c|} 
Vehicle Upset \\
resulting from \\
control surface \\
failure - Slat \\
Asymmetry: \\
Aircraft's No. 7 \\
leading edge slat (on \\
its right wing) was \\
stuck in the extended \\
or partially extended \\
position and could \\
not be retracted (due \\
to a pre-existing \\
misalignment and the \\
resulting air loads); \\
No. 7 slat was torn \\
from the aircraft
\end{tabular} & $\begin{array}{c}\text { System / Component } \\
\text { Failure - Flight Control } \\
\text { System }\end{array}$ & 126 \\
\hline
\end{tabular}




\section{Acknowledgments}

This research is dedicated to the memory of Dr. Celeste M. Belcastro of NASA Langley Research Center, who lost her courageous and selfless battle with cancer and passed from this life on August 22, 2008. She dedicated her life and career to aviation safety research, and made numerous technical and leadership contributions in the areas of vehicle health management and safety-critical avionics systems. Just prior to her illness, she had embarked on a research collaboration with her identical twin, Dr. Christine M. Belcastro, to address aircraft loss of control. Her absence from this work will forever be a significant and irreparable loss to the aerospace research community.

The authors wish to thank Dr. Steven D. Young for insight into NextGen and the identification of new LOC precursors for future systems and operations, and to Mr. Kenneth H. Goodrich for numerous suggestions for improvement of the paper during its review.

\section{References}

1 "Statistical Summary of Commercial Jet Airplane Accidents, Worldwide Operations, 1959-2008”, Boeing Commercial Airplanes, July 2009. Available at http://www.boeing.com/news/techissues.

${ }^{2}$ Lambregts, A. A., Nesemeier, G., Wilborn, J. E., and Newman, R. L., "Airplane Upsets: Old Problem, New Issues”, AIAA Modeling and Simulation Technologies Conference and Exhibit, 2008, AIAA 2008-6867.

${ }^{3}$ Evans, Joni K., “An Examination of In Flight Loss of Control Events During 1988-2004”, Alliant Techsystems, Inc., NASA Langley Research Center, Contract No.: TEAMS:NNL07AM99T/R1C0, Task No. 5.2, 2007.

${ }^{4}$ Jacobson, Steven R., Foster, John V., Casner, Stephen M., Reehorst, Andrew L., Addy, Harold E., Shah, Gautam H., and Nowinski, Jessica L., “Aircraft Loss of Control Study Final Report”, February 2010.

${ }^{5}$ Aviation Safety Network (ASN) Database Available at http://aviation-safety.net/database/

${ }_{7}^{6}$ National Transportation Safety Board (NTSB) Database Available at http://www.ntsb.gov/ntsb/query.asp

7 Joint Planning and Development Office, "Concept of Operations for the Next Generation Air Transportation System”, Version 3, October 2009, Available at http://www.jpdo.gov/library.asp 
Filename: $\quad$ Aircraft LOC Accident Analysis - Paper_Belcastro_Final.doc

Directory: $\quad$ C:IDocuments and Settingslcbelcast $\mid$ My Documents

Template: C:IDocuments and Settings/cbelcast\Application

Data $\backslash$ Microsoft $\backslash$ Templates $\backslash$ Normal.dotm

Title:

Subject:

Author:

Keywords:

Comments:

Creation Date: $\quad$ 7/14/2010 11:03:00 AM

Change Number: $\quad 44$

Last Saved On: $\quad$ 7/23/2010 3:27:00 PM

Last Saved By: cbelcast

Total Editing Time: $\quad$ 1,754 Minutes

Last Printed On: $\quad$ 7/23/2010 3:27:00 PM

As of Last Complete Printing

Number of Pages: $\quad 40$

Number of Words: $\quad$ 10,417 (approx.)

Number of Characters: $\quad 59,381$ (approx.) 